\title{
Leptostracans (Crustacea: Phyllocarida) from mud volcanoes at the Gulf of Cadiz (NE Atlantic) with description of a new species of Sarsinebalia Dahl, 1985
}

\author{
Juan MOREIRA ${ }^{1, *}$, Patricia ESQUETE ${ }^{2} \&$ Marina R. CUNHA ${ }^{3}$ \\ ${ }^{1}$ Departamento de Biología (Zoología) \& Centro de Investigación en Biodiversidad y Cambio Global \\ (CIBC-UAM), Facultad de Ciencias, Universidad Autónoma de Madrid, \\ Cantoblanco, E-28049 Madrid, Spain. \\ ${ }^{2,3}$ CESAM - Centre for Environmental and Marine Studies, Departamento de Biologia, \\ Universidade de Aveiro, Campus de Santiago, 3810-193 Aveiro, Portugal. \\ *Corresponding author: juan.moreira@uam.es \\ 2Email: pesquete@ua.pt \\ ${ }^{3}$ Email: marina.cunha@ua.pt \\ ${ }^{1}$ urn:lsid:zoobank.org:author:B1E38B9B-7751-46E0-BEFD-7C77F7BBBEF0 \\ ${ }^{2}$ urn:1sid:zoobank.org:author:DD6A9296-5310-4816-A125-9E37691E14AF \\ ${ }^{3}$ urn:1sid:zoobank.org:author:553A98B5-0AE0-424F-9ED5-EC50F129519C \\ ${ }^{1} \odot$ https://orcid.org/0000-0002-1374-2033
2 - https://orcid.org/0000-0002-9595-1524
${ }^{3} \odot$ https://orcid.org/0000-0001-8833-6980
}

\begin{abstract}
Three leptostracan species (Crustacea: Phyllocarida) are reported from mud volcanoes at the Moroccan margin of the Gulf of Cadiz (NE Atlantic). Nebalia strausi Risso, 1826 and N. abyssicola Fage, 1929 were found in experimentally deployed organic substrates in Mercator, Meknès and Darwin mud volcanoes; $N$. abyssicola was also found among bathymodiolin bivalves and is recorded for the first time in the Atlantic Ocean. The third species was collected from the Gemini mud volcanoes and is described herein as Sarsinebalia ledoyeri sp. nov. The new species is characterised by having the eyes provided with ommatidia and lacking pigment, the ventral margin of the eye is concave along distal half, the antennular scale is more than twice as long as wide, the second article of the mandibular palp bears one seta on lateral surface about 0.5 times as long as the article and one subterminal seta longer than the third article, the distal article of the maxilla II endopod is about 1.8 times as long as the proximal article, the maxilla II exopod is clearly longer than the endopod proximal article, the lateral margin of the pleopod I exopod lacks setae and the posterodorsal border of pleonites VI-VII is provided with rounded to pointed denticles.
\end{abstract}

Keywords. Crustacea, Leptostraca, new species, NE Atlantic, mud volcanoes.

Moreira J., Esquete P. \& Cunha M.R. 2021. Leptostracans (Crustacea: Phyllocarida) from mud volcanoes at the Gulf of Cadiz (NE Atlantic) with description of a new species of Sarsinebalia Dahl, 1985. European Journal of Taxonomy 736: 102-136. https://doi.org/10.5852/ejt.2021.736.1255 


\section{Introduction}

The number of known species of extant leptostracans (Crustacea: Phyllocarida) has been substantially expanded in the last decades, with descriptions of new taxa from many areas around the globe, including North and Central America (Modlin 1991; Escobar-Briones \& Villalobos-Hiriart 1995; Martin et al. 1996; Vetter 1996b; Haney \& Martin 2000, 2004, 2005; Haney et al. 2001; Ortiz et al. 2011), eastern and southeast Asia (Lee \& Bamber 2011; Song et al. 2012b, 2013, 2017; Song \& Min 2017), southwest Africa (Bochert \& Zettler 2012), western Pacific Ocean (Ledoyer 2000) and Australia (Walker-Smith 1998, 2000). In the northeast Atlantic, following the review of European leptostracans by Dahl (1985), new taxa have been described and new records reported from across the Atlantic coasts (Ledoyer 1998; Moreira et al. 2003a, 2003b, 2009a; McCormack et al. 2016) and the Mediterranean Sea (Ledoyer 1997; Koçak \& Katagan 2006; Koçak \& Moreira 2015; Moreira et al. 2007, 2012; Moreira \& Junoy 2017). Most of the extant leptostracan species belong to the genus Nebalia Leach, 1814, for a total of 11 species in European latitudes and the Mediterranean Sea (Dahl 1985; Ledoyer 1997; Moreira et al. 2009a; Koçak et al. 2011; McCormack et al. 2016; Latry \& Droual 2020). The genera Nebaliella Thiele, 1904, Sarsinebalia Dahl, 1985 and the pelagic Nebaliopsis Sars, 1887 and Pseudonebaliopsis Petryashov, 1996 have also been recorded from the NE Atlantic (Mauchline \& Gage 1983; Dahl 1985) while Paranebalia Claus, 1880 has been recently reported from the Mediterranean Sea (Moreira \& Junoy 2017).

Regarding the genus Sarsinebalia, four species have been described from NE Atlantic (Sars 1870; Ledoyer 1998; Moreira et al. 2003b) for a total of six worldwide (Dahl 1985; Ledoyer 2000; Petryashov 2016). The validity of the genus was challenged by the phylogenetic analyses of Walker-Smith \& Poore (2001) and later discussed by Moreira et al. (2003b) and McCormack et al. (2016). The type species of the genus, S. typhlops (G.O. Sars, 1870), was considered as having a large distribution across the North Atlantic and the Mediterranean, including the subspecies S. typhlops occidentalis (Hessler \& Sanders, 1965) from the NW Atlantic; the latter, however, has been suggested to be a different species that might deserve revision and eventually raised to the species rank (Dahl 1985). There are three other species described from European temperate latitudes: S. biscayensis Ledoyer, 1998 from deep-sea waters at the Bay of Biscay, and S. cristoboi Moreira et al., 2003 and S. urgorrii Moreira et al., 2003, both from shallow coarse and medium sand at the western Iberian Peninsula (Moreira et al. 2003b; Sampaio et al. 2016); S. urgorrii has also been reported from around the British Isles (McCormack et al. 2016) and French Atlantic and Mediterranean waters (Latry \& Droual 2020). Species mostly differ in the presence of ommatidia and pigment (both absent in S. typhlops, S. biscayensis and S. pseudotyphlops Petryashov, 2016) and the shape of eye.

Most leptostracans are epifaunal and present in a variety of hard and soft substrata, mainly in shallow waters $(<100 \mathrm{~m}$ depth) (Haney \& Martin 2016). However, some species are present at greater depths (Mauchline \& Gage 1983; Hessler 1984; Haney et al. 2001), even reaching the abyssal realm (> $5000 \mathrm{~m}$ depth; Petryashov 2016), but the knowledge about the actual diversity and ecology of deep-sea leptostracans is still incomplete and many areas still remain unexplored.

Mud volcanoes (MVs hereafter) are cold-seep related structures formed by the extrusion of sediments with venting of hydrocarbon-rich fluids (mostly methane) that allows for the presence of chemosymbiotic species (Levin 2005; Cunha et al. 2013b; Rodrigues et al. 2013) and a diverse associated benthic assemblage in comparison to other cold-seep formations (e.g., Cunha et al. 2013b; González-García et al. 2020). MVs are frequent (ca 40) in the Gulf of Cadiz (southern Iberian margin, NE Atlantic) and located at depths of between 200 and $4000 \mathrm{~m}$ (Cunha et al. 2013b). Several studies conducted in MVs at the Moroccan margin of the Gulf of Cadiz yielded a number of leptostracan specimens corresponding to three species, namely Nebalia strausi Risso, 1826, Nebalia abyssicola Fage, 1929 and a new species of Sarsinebalia that is described herein as Sarsinebalia ledoyeri sp. nov. To our knowledge, these findings constitute the first reports of leptostracans identified to the species level for MVs and the first record of N. abyssicola in the Atlantic Ocean. 


\section{Material and methods}

Specimens of $N$. strausi and $N$. abyssicola were retrieved in the framework of the CHEMECO project (European Science Foundation, EuroDEEP programme) aiming to study the colonization process in organic substrata experimentally deployed in several MVs at the Gulf of Cadiz within the Moroccan EEZ (Fig. 1). The colonization experiment consisted in the deployment of sets of three standardized units (i.e., CHEMECOLI, see Gaudron et al. 2010 for details), each including a different substrate treatment: dried alfalfa grass (organic), Douglas fir wood cubes (organic) and carbonate cubes (inorganic/control) enclosed by a $2 \mathrm{~mm}$ mesh net. The sets of colonization units were deployed with a ROV in 2007 during the RRS James Cook Cruise 10 (JC10) and in 2008 during the RV Pelagia Cruise 284 (64PE284) along a depth gradient across the continental slope on the crater of the following MVs: Mercator MV in the El Arraiche Field (350 m depth); Meknès and Darwin MVs in the Carbonate Province (700 and $1100 \mathrm{~m}$ depth, respectively). One set from Mercator MV was recovered also using a ROV in 2008 (cruise 64PE284) and the others in 2009 during the RV Belgica Cruise B09-14b; the metadata of the experiments, including the duration of the deployments are listed in Table 1. Description of experimental procedures and treatment of samples can be found in Cunha et al. (2013a). Samples were not sieved and sub-samples of the substrates enclosed by the net were directly fixed in a solution of $95 \%$ ethanol or in $10 \%$ formalin. External components of the CHEMECOLI units were washed and all fauna present was fixed and kept separately for further examination. Specimens of $N$. abyssicola were also retrieved from three ROV suction samples $(250 \mu \mathrm{m}$ mesh) carried out at the experimental site on the crater of Darwin MV from aggregations of the chemosymbiotic bivalve Gigantidas mauritanicus (Cosel, 2002)

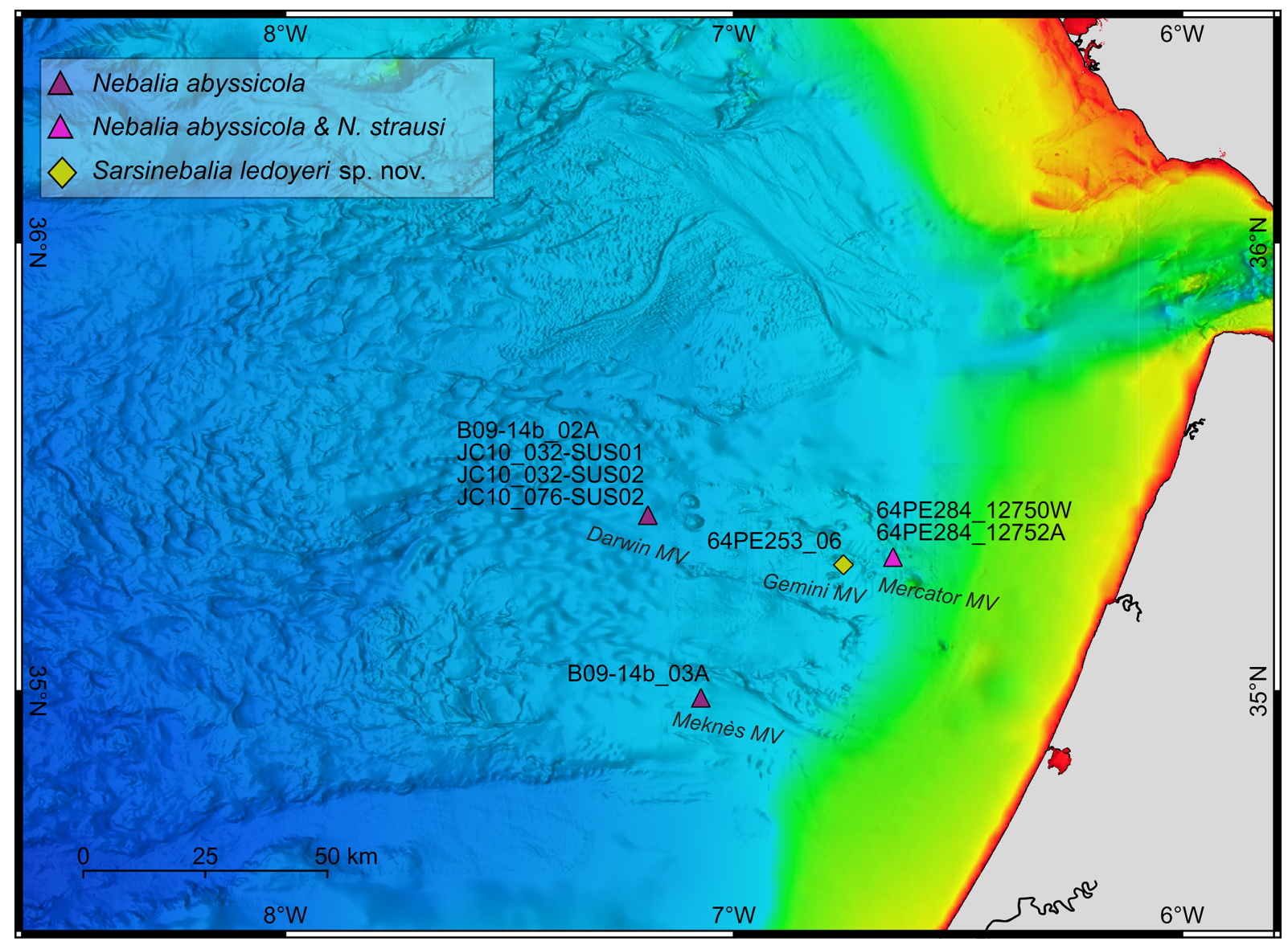

Fig. 1. Location of sampling sites in the mud volcanoes (Darwin, Gemini, Meknès, Mercator) at the Gulf of Cadiz within the Moroccan EEZ. Codes refer to samples obtained at each site. 
Table 1. Metadata of the deployment and recovery of the colonization experiments in the Gulf of Cadiz. Abbreviations: $\mathrm{DD}=$ deployment duration; $\mathrm{MV}=$ mud volcano.

\begin{tabular}{|c|c|c|c|c|c|c|c|c|c|}
\hline \multirow[b]{2}{*}{ Site } & \multicolumn{3}{|c|}{ Site coordinates } & \multicolumn{2}{|c|}{ Deployment } & \multicolumn{2}{|c|}{ Recovery } & \multirow[b]{2}{*}{ Sample } & \multirow{2}{*}{$\frac{\text { DD }}{\text { (days) }}$} \\
\hline & Latitude & Longitude & Depth & Cruise & Date & Cruise & Date & & \\
\hline Mercator MV & $35^{\circ} 17.916^{\prime} \mathrm{N}$ & $06^{\circ} 38.709^{\prime} \mathrm{W}$ & $354 \mathrm{~m}$ & $\mathrm{JC} 10$ & 19 May 2007 & $\begin{array}{l}\text { 64PE284 } \\
\text { 64PE284 }\end{array}$ & $\begin{array}{l}2 \text { Mar. } 2008 \\
3 \text { Mar. } 2008\end{array}$ & $\begin{array}{l}\text { 64PE284_12750W } \\
\text { 64PE284_12752A }\end{array}$ & $\begin{array}{l}290 \\
291\end{array}$ \\
\hline Meknès MV & $34^{\circ} 59.091^{\prime} \mathrm{N}$ & $07^{\circ} 04.424^{\prime} \mathrm{W}$ & $698 \mathrm{~m}$ & 64PE284 & 1 Mar. 2008 & B09-14b & 20 May 2009 & B09-14b_03A & 446 \\
\hline Darwin MV & $35^{\circ} 23.523^{\prime} \mathrm{N}$ & $07^{\circ} 11.513^{\prime} \mathrm{W}$ & $1100 \mathrm{~m}$ & $\mathrm{JC} 10$ & 21 May 2007 & B09-14b & 19 May 2009 & B09-14b 02A & 629 \\
\hline
\end{tabular}

(previously referred to as "Bathymodiolus" mauritanicus; see Génio et al. 2008). Two of these samples were obtained just after the deployment of the colonization units.

Specimens of Sarsinebalia ledoyeri sp. nov. were collected in 2006 in the Gemini MV by means of a NIOZ box corer (see de Haas \& Shipboard Scientific Party 2006 for details; Fig. 1). Sediment samples were layered $(0-2 \mathrm{~cm}, 2-5 \mathrm{~cm}, 5-10 \mathrm{~cm}, 10-20 \mathrm{~cm})$, washed through a sieve column $(2,1,0.5 \mathrm{~mm})$ and the fauna preserved in $96 \%$ ethanol.

Line drawings of specimens, dissected parts and appendages were done with the aid of a camera lucida connected to a compound microscope. Drawings of Sarsinebalia ledoyeri sp. nov. correspond to several dissected postovigerous and preovigerous females and males (specimens were particularly brittle); the drawing of the lateral view of a full specimen corresponds to the holotype. Measurements were made with an ocular micrometer. The following measurements were considered: Total Length (TL): distance from the articulation between the rostrum and carapace to the posterior end of the uropods excluding setation; Dorsal Carapace Length (DCL): distance between the articulation of the rostrum and the margin of the posterodorsal cleft; Lateral Carapace Length (LCL): distance along lateral surface between the anterior-most and posterior-most margin; Carapace Height $(\mathrm{CH})$ : distance between the dorsal and ventral margin; Rostrum Length (RL): distance along the midline. Descriptions are based on females; complementary data for males are also given. Descriptions of $N$. strausi and $N$. abyssicola are limited to relevant diagnostic characters; the new species Sarsinebalia ledoyeri sp. nov. is fully described. Terminology for setae follows Watling (1989) and Walker-Smith (2000). Specimens of $N$. strausi and N. abyssicola are deposited in the Biological Research Collection (Marine Invertebrates) of the Department of Biology of the University of Aveiro (COBI-DBUA; Portugal); the holotype and some paratypes of Sarsinebalia ledoyeri sp. nov. in the Museo Nacional de Ciencias Naturales (MNCN, Madrid) and remaining paratypes in COBI-DBUA.

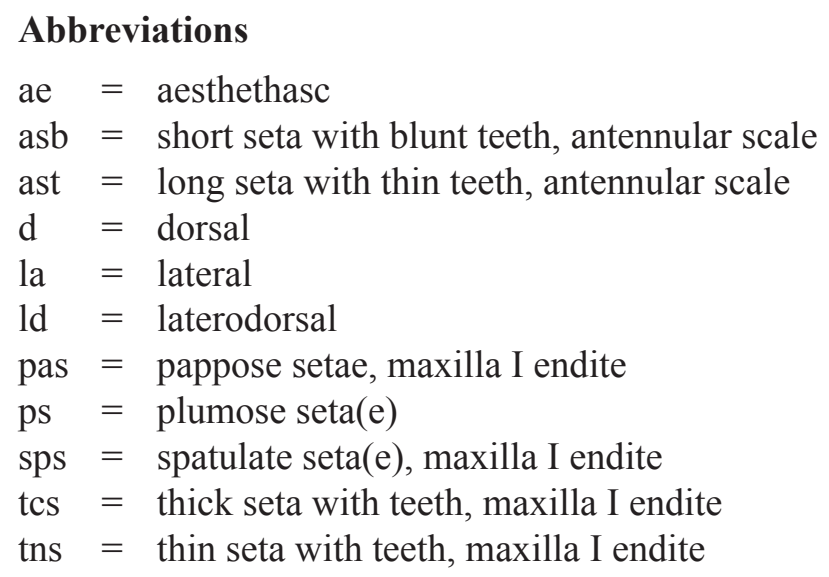




\section{Results}

Order Leptostraca Claus, 1880

Suborder Nebaliacea Calman, 1904

Family Nebaliidae Samouelle, 1819

Genus Nebalia Leach, 1814

Nebalia strausi Risso, 1826

Figs 1-5

Nebalia straus Risso, 1826: 84, pl. V, fig. 20.

Nebalia straus - Koçak \& Katagan 2006: 321, figs 1-3. — Koçak et al. 2007: 449, figs 1-3.

Nebalia strausi - Dahl 1985: 155, figs 63-79. — Ledoyer 1997: 34, fig. 4. — Moreira et al. 2004: 84, figs 1-7; 2009b: 101, lam. 1, figs 1-3.

\section{Material examined}

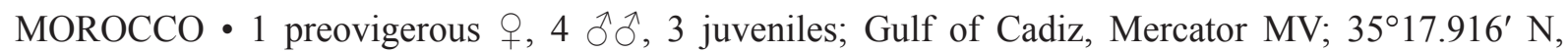
06³8.709' W; 354 m depth; 2 Mar. 2008; St 64PE284_12750W, experimentally deployed wood

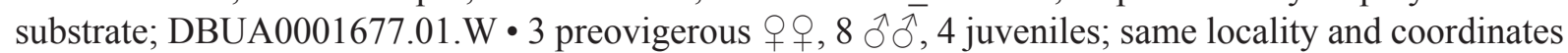
as for preceding; 3 Mar. 2008; St 64PE284_12752A, experimentally deployed alfalfa substrate; DBUA0001677.02.A.

\section{Description of female}

MEAsurements. Preovigerous females measuring TL 5.275-5.8 mm, RL 0.925-1.025 mm, DCL 2.15$2.25 \mathrm{~mm}$, LCL $2.675-3.0 \mathrm{~mm}, \mathrm{CH} 1.825-1.95 \mathrm{~mm}$.

Carapace, rostrum and eye. Carapace covering at least lateral sides of pleonites 1-4; LCL about 1.5 times $\mathrm{CH}$. Rostrum long, with parallel margins, length about 2.3 times width, 0.45 times DCL (Fig. 2A, C). Eye about 0.65 times as long as rostrum; ommatidia numerous, distributed about $5 / 6$ of eye (Fig. 2B); dark pigment in most ommatidia.

ANTENNAE. Antennule peduncle fourth article with anterior row of 5-6 simple setae and two distal robust setae, proximal one shorter (Fig. 2D), juveniles $(<4 \mathrm{~mm} \mathrm{TL})$ with one robust seta; antennular scale length 2.25-2.4 times width; flagellum with up to 11-13 articles. Antenna peduncle third article lateral margin with three proximal plumose setae on proximal half and three distal spine-like setae (Fig. 2E-F); flagellum with up to 11-14 articles (Fig. 2E).

MouthPARTS. Mandibular palp second article with two subequal setae: one seta setulose along distal half on lateral margin at mid-length and one simple seta on distal third; third article slightly longer than second (Fig. 3A). Maxilla I palp well-developed, about 4.5 times as long as protopod (Fig. 3B). Maxilla II endopod proximal article about 1.5-1.6 times as long as distal article; exopod longer than endopod first article (Fig. 3C).

THORACOPODS. Endopod slightly longer than exopod (Fig. 3D-E); endopod distal article slightly enlarged, with several (ca 10) setae; endopod segmentation weak. Thoracopod VIII epipod smaller than in other thoracopods and lacking setae (Fig. 3F).

Pleonites AND PLeOPODS. Pleonite IV epimeron posterolateral corner slightly pointed (Fig. 4C). Pleonites VI-VII posterodorsal border bearing denticles acutely pointed (Fig. 4G-H). Pleopod I exopod about 0.72 times as long as protopod and endopod; lateral border with 'comb-row' of ca 30 bi-pectinate setae 
(sensu Walker-Smith 2000) (Fig. 4A); protopod with long seta near base of exopod, hardly reaching middle of 'comb-row'. Pleopods II-IV exopod with row of 5-7 pairs of smooth setae ('spine pairs') (Fig. 4B). Pleopod IV protopod posterior border with four serrations. Pleopod V distal article 3.4 times as long as wide, with five simple setae along distolateral and terminal margins, proximal-most the shortest

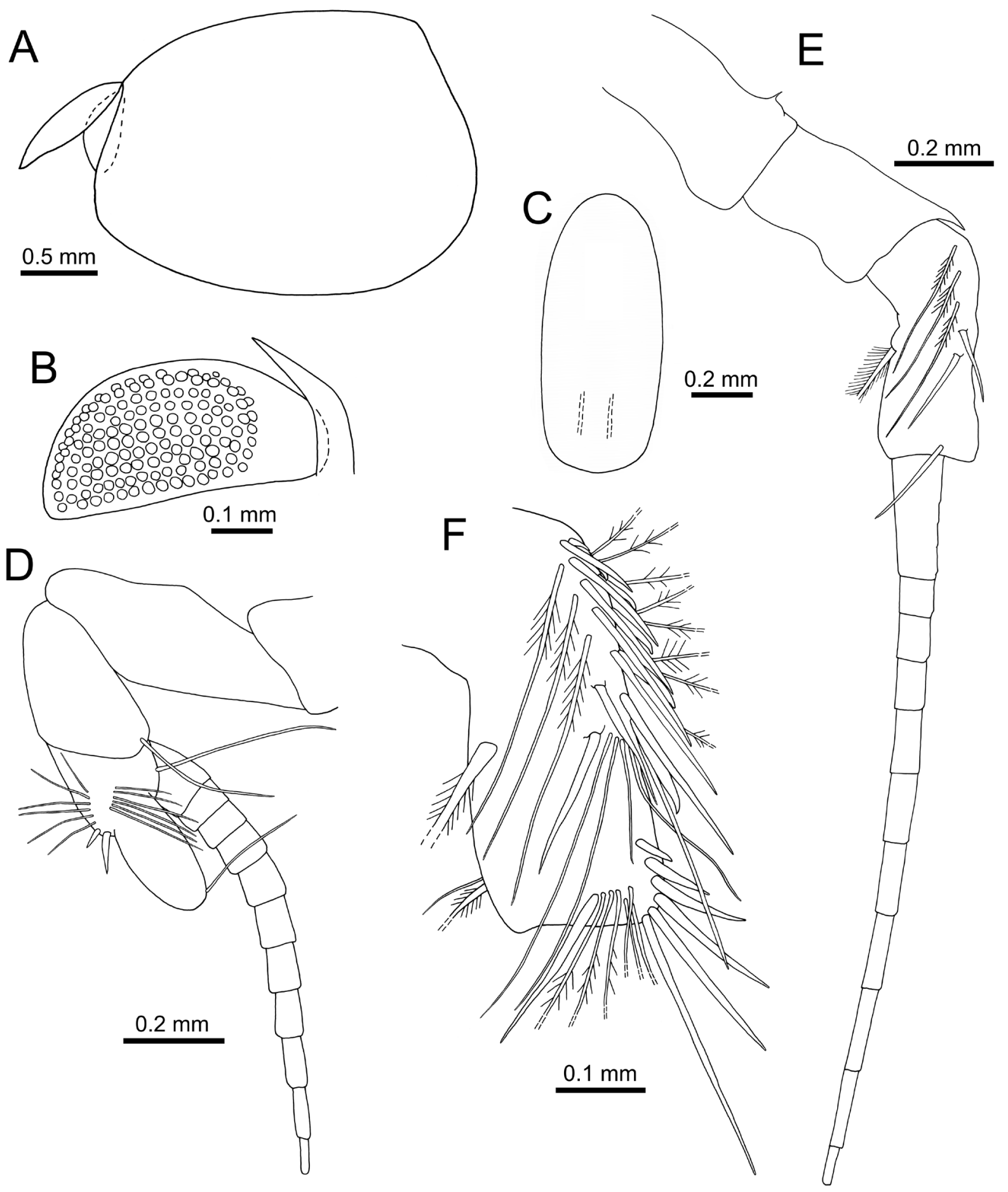

Fig. 2. Nebalia strausi Risso, 1826. Preovigerous female (DBUA0001677.01.W). A. Rostrum, eye and carapace outline, lateral view. B. Eye and supra-orbital plate, lateral view. C. Rostrum, dorsal view. D. Antennule, lateral view. E. Antenna, lateral view. F. Antenna, peduncle third article, lateral view. D-E: only selected setae illustrated. 
(Fig. 4D). Pleopod VI 2.0 times as long as wide, with five simple setae along lateral and terminal margins, distal-most the longest (Fig. 4E). Pleopod V-VI pairs with acute triangular process between rami bases.

ANAL SOMITE, ANAL PLATES AND UROPODS. Anal somite 0.8-0.95 times as long as pleonite VII. Anal plates acutely tapering distally, 'shoulder' well-defined (Fig. 4F, I). Uropods 0.8-0.92 times as long as pleonite $\mathrm{VII}+$ anal somite; terminal seta 1.7 times as long as ramus.
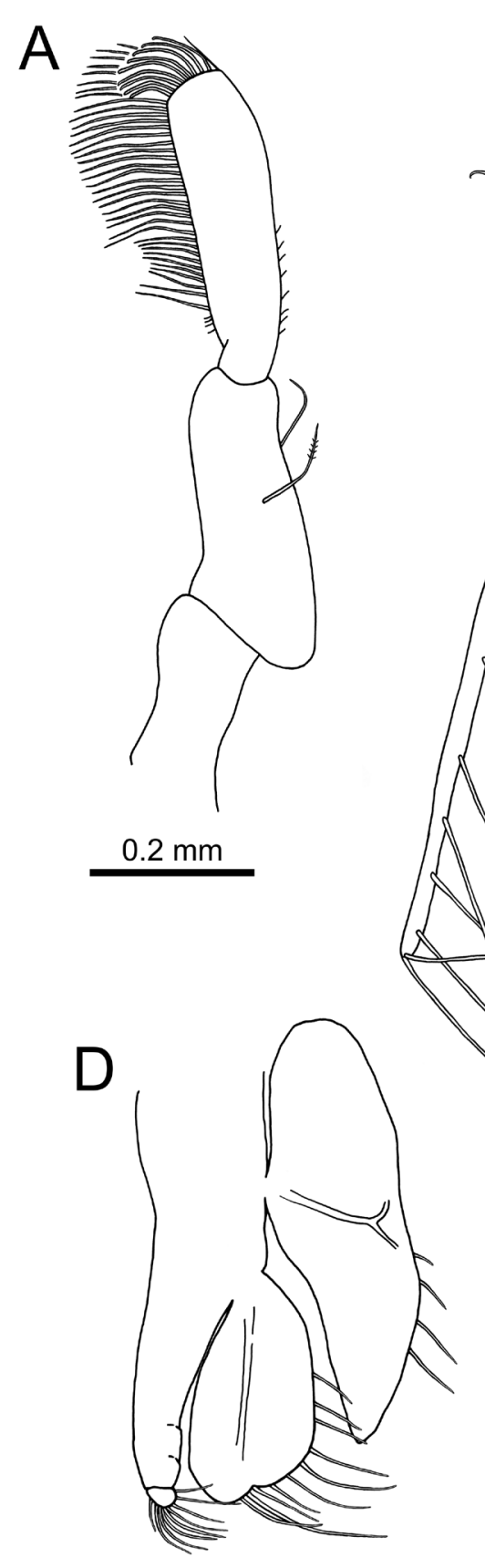

B
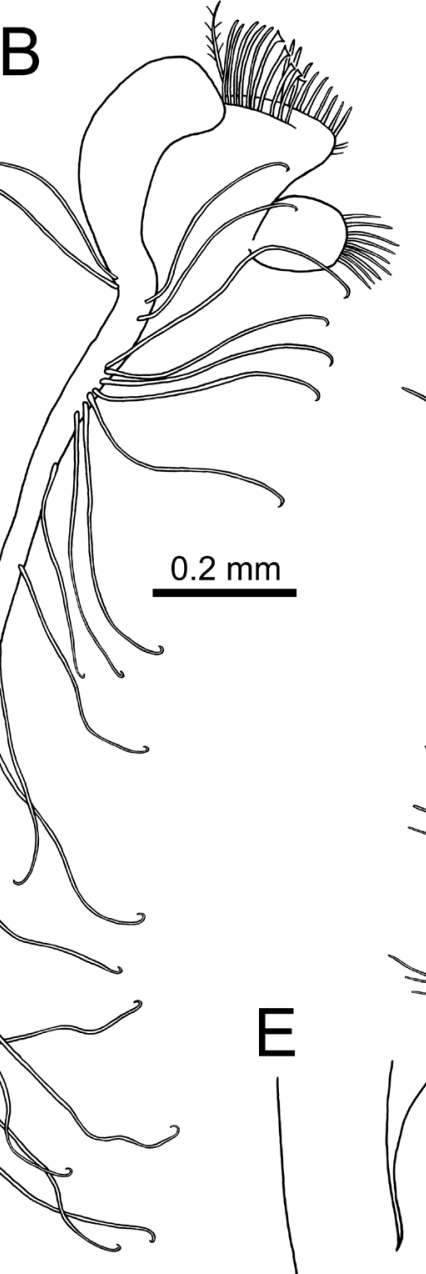

$0.2 \mathrm{~mm}$
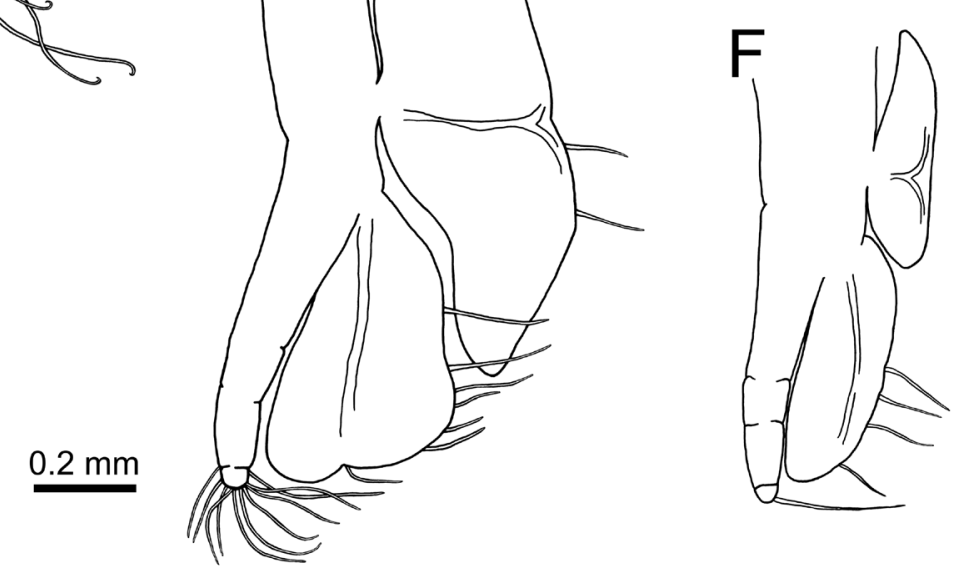

Fig. 3. Nebalia strausi Risso, 1826. Preovigerous female (DBUA0001677.01.W). A. Mandibular palp. B. Maxilla I. C. Maxilla II. D. Thoracopod II. E. Thoracopod V. F. Thoracopod VIII. D-F: same scale bar; C: setules and endites' setae not illustrated; D-F: only selected setae illustrated. 


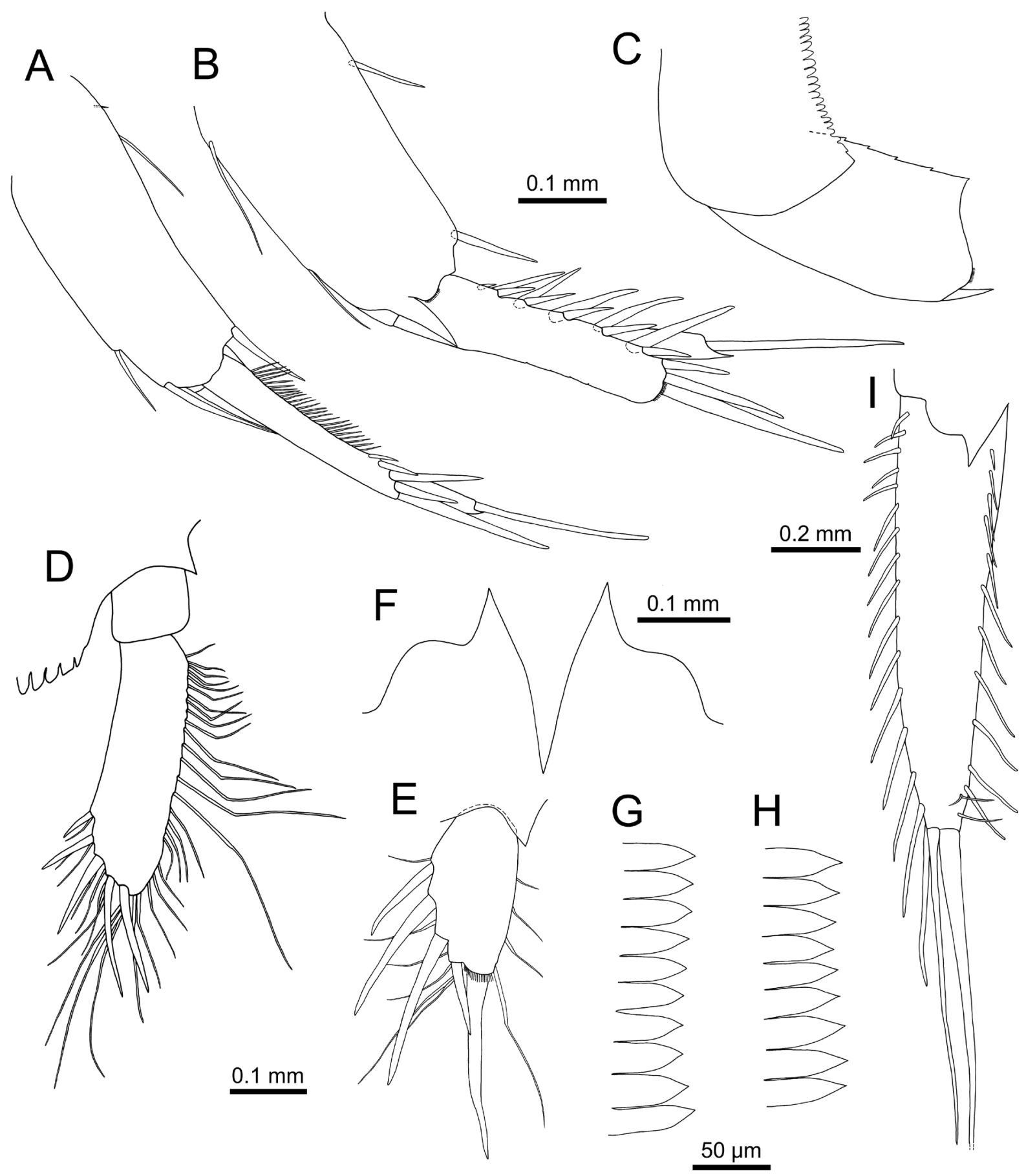

Fig. 4. Nebalia strausi Risso, 1826. Preovigerous female (DBUA0001677.01.W). A. Pleopod I, lateral view. B. Pleopod II, lateral view. C. Pleonite IV, epimeron and pleopod IV protopod, lateral view. D. Pleopod V, ventral view. E. Pleopod VI, ventral view. F. Anal plates, ventral view. G. Pleonite VI, posterior dorsal and laterodorsal border, denticles. H. Pleonite VII, posterior dorsal and laterodorsal border, denticles. I. Right uropod and anal plate, ventral view. A-C, D-E, G-H: same scale bars; A-B, I: plumose setae not illustrated. 


\section{Description of male}

TL 3.95-5.375 mm, RL 0.825-1.05 mm, DCL 1.575-2.125 mm, LCL 2.2-3.0 mm, CH 1.625-1.925 mm. Carapace proportions (LCL:CH) similar to females (Fig. 5A). Ommatidia and dark pigment covering $5 / 6$ of eye (Fig. 5B). Antennule peduncle fourth article with 1-2 distal robust setae; antennular scale proportions similar to females (2.25-2.30 times as long as wide) (Fig. 5D); flagellum with up to 10-12 articles, thicker than in females. Antenna peduncle third article lateral margin with similar setation as in females; flagellum with many articles (>30) but not surpassing TL (Fig. 5C). Pleonites VI-VII denticles acutely pointed. Pleopod IV protopod posterior border with four serrations. Uropods length similar to females.

\section{Remarks}

Nebalia strausi is a well-known species that is characterized by having ommatidia and dark pigment extending through most of the eye; the antennular scale is more than twice as long as wide; the fourth article of antennule peduncle bears two distal robust setae of different length; the exopod of maxilla II surpasses the level of articulation of endopod articles, and the endopod proximal article is clearly longer than the distal one; the posterolateral corner of the pleonite IV epimeron is not acutely produced; the posterior margin of pleopod IV protopod bears four serrations; and the posterodorsal denticles of pleonites VI-VII are acutely pointed (Dahl 1985; Ledoyer 1997; Moreira et al. 2004). Furthermore, the terminal simple seta of the pleopod I protopod barely reaches half-length of the 'comb-row' and
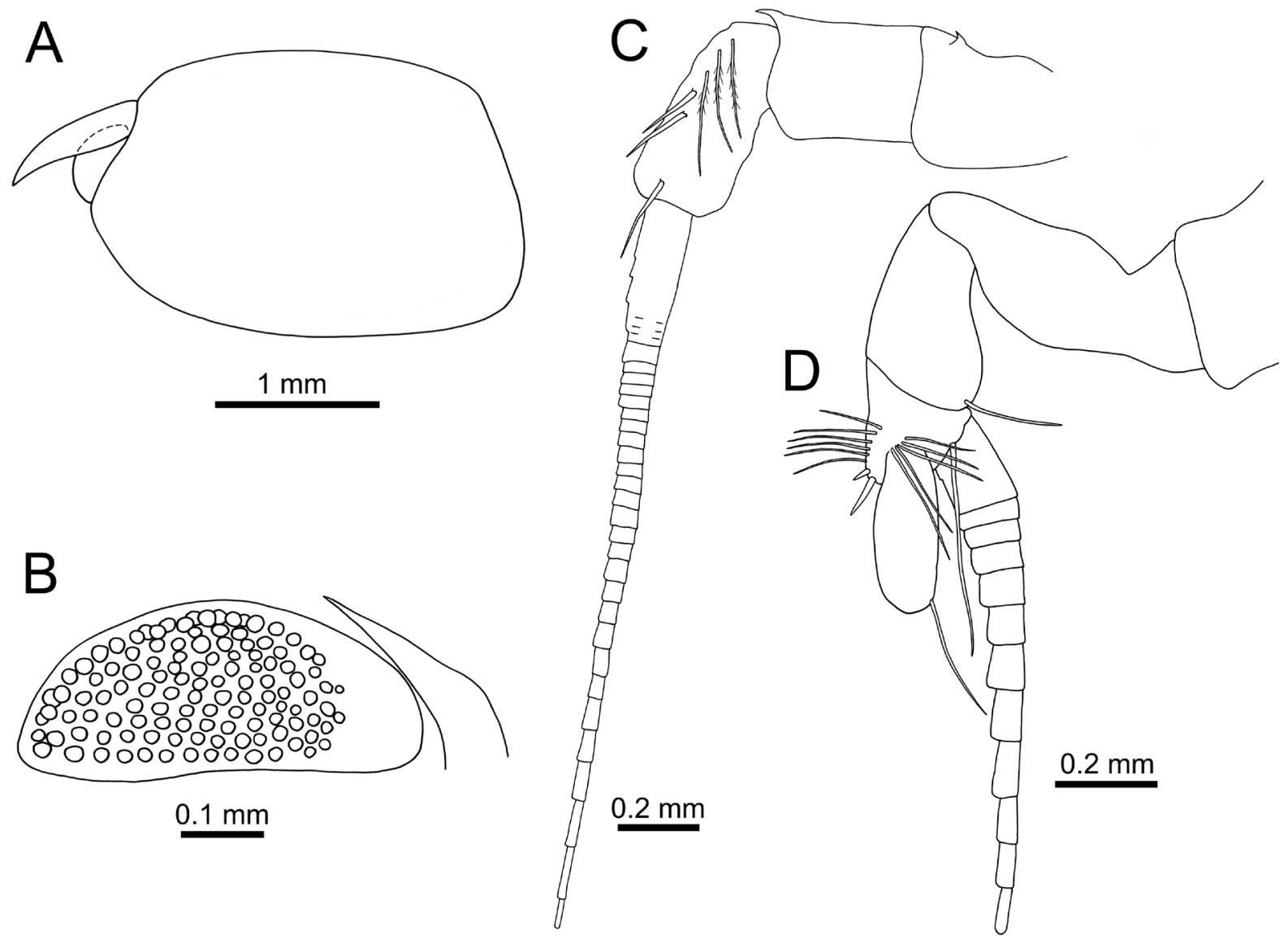

Fig. 5. Nebalia strausi Risso, 1826. Male (DBUA0001677.01.W). A. Rostrum, eye and carapace outline, lateral view. B. Eye and supra-orbital plate, lateral view. C. Antenna, lateral view. D. Antennule, lateral view. C-D: only selected setae illustrated. 
the uropods are at least as long as pleonite VII and anal somite combined, and slightly longer in mature specimens (Dahl 1985).

Specimens from Mercator MV mostly agree with the diagnosis of the species. The only minor difference is that the uropods are slightly shorter, but this may be due to the state of development, i.e., no specimen was fully mature. Note that the organic substrates where the specimens were found were enclosed by a $2 \mathrm{~mm}$ mesh size net, and it is likely that the specimens settled on the substrates as juveniles just released from the brood pouch. The anal plates have an even more prominent shoulder than in the Mediterranean specimens described by Dahl (1985); those reported by Ledoyer (1997) bear, in turn, a gently sloping 'shoulder', whereas there is almost no 'shoulder' at all in those described by Moreira et al. (2004) from the NW Iberian Peninsula. Most specimens bear two robust setae on the fourth article of antennule peduncle but small males and juveniles bear instead only one. Moreira et al. (2004) reported similar observations in immature females whereas ovigerous and postovigerous females always had two robust setae of different length. Number of setae is known to vary during ontogeny (Dahl 1985) and therefore this character should be considered with care for identification unless fully-grown specimens are available; this also applies for the number of articles in the antennae flagella that are fewer on juveniles. On the other hand, some minor variations have also been reported for specimens from the eastern Mediterranean (Koçak et al. 2010) and therefore the possibility of a complex of species across its wide distribution range has been suggested (Koçak et al. 2011).

\section{Ecology}

Recorded from the intertidal to depths of $140 \mathrm{~m}$, in rocky substrates and sandy and muddy soft bottoms, and among the seagrasses Zostera marina L., 1753, Z. noltii Hornem., 1832, Cymodocea sp. and Posidonia oceanica (L.) Delile, 1813 (Dahl 1985; Ledoyer 1997; Moreira et al. 2004, 2009a, 2009b; Koçak et al. 2007; Latry \& Droual 2020). The present findings of the species from experimentally deployed wood and alfalfa substrates at the Mercator MV extend its known bathymetric range to depths of $354 \mathrm{~m}$.

\section{Distribution}

SW European Atlantic from north western Ireland to NW Iberian Peninsula (Dahl 1985; Moreira et al. 2004, 2009a, 2009b; McCormack et al. 2016; Latry \& Droual 2020); Mediterranean Sea (Dahl 1985; Ledoyer 1997; Koçak \& Katagan 2006; Koçak et al. 2011; Latry \& Droual 2020); Canary Islands (Dahl 1985; Moreira et al. 2009b), Madeira and St Helena (Dahl 1985); Moroccan margin of the Gulf of Cadiz (this study; Fig. 1).

Nebalia abyssicola Fage, 1929

Figs 1, 6-9

Nebalia bipes abyssicola Fage, 1929: 41, pl. III, figs 88-89.

Nebalia abyssicola - Ledoyer 1997: 29, fig. 1. — Moreira et al. 2012: 352, figs 1-5.

\section{Material examined}

MOROCCO $\bullet 1$ preovigerous + , $6 \hat{\partial^{\lambda}}$, 1 juvenile; Gulf of Cadiz, Mercator MV; $35^{\circ} 17.916^{\prime} \mathrm{N}$, 06³8.709' W; $354 \mathrm{~m}$ depth; 2 Mar. 2008; St 64PE284_12750W, experimentally deployed wood substrate; DBUA0001676.01.W $\bullet 4$ preovigerous $ᄋ$ ㅇ, $5 \hat{\partial^{\circ}}, 3$ juveniles; same locality and coordinates as for preceding; 3 Mar. 2008; St 64PE284_12752A, experimentally deployed alfalfa substrate;

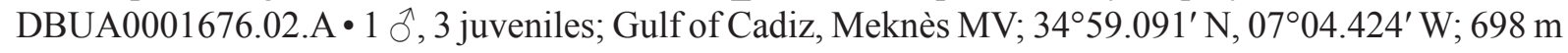
depth; 20 May 2009; St B09-14b_03A, experimentally deployed alfalfa substrate; DBUA0002350.02.A • 


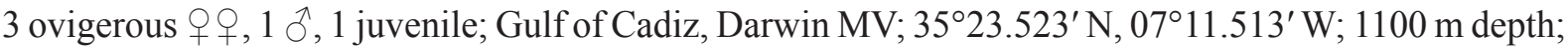
19 May 2009; St B09-14b_02A, experimentally deployed alfalfa substrate; DBUA0002350.01.A • 2 우, 2 ○े $\widehat{0}, 25$ juveniles; same locality and coordinates as for preceding; $1109 \mathrm{~m}$ depth; 21 May 2007; St JC10_032-SUS01, suction sample from Bathymodiolinae bed; DBUA0002392.01 - 2 q 11 juveniles; same locality and coordinates as for preceding; $1110 \mathrm{~m}$ depth; 22 May 2007; St JC10_032SUS02, suction sample from Bathymodiolinae bed; DBUA0002392.02 3 juveniles; same locality and coordinates as for preceding; $1110 \mathrm{~m}$ depth; 1 Jun. 2007; St JC10_076-SUS01, suction sample from Bathymodiolinae bed; DBUA0002392.03.

\section{Description of female}

MEAsuREMENTs. Ovigerous 우: TL 6.0-6.625 mm, RL 1.05-1.125 mm, DCL 2.375-2.5 mm, LCL 3.0$3.125 \mathrm{~mm}, \mathrm{CH} 2.125-2.25 \mathrm{~mm}$; preovigerous 우우: TL 4.6-6.5 mm, RL 0.75-0.925 mm, DCL 1.75$2.25 \mathrm{~mm}$, LCL $2.125-2.875 \mathrm{~mm}, \mathrm{CH} 1.5-1.925 \mathrm{~mm}$.

Carapace, Rostrum and eye. Carapace covering at least lateral sides of pleonites 1-4 (Fig. 6A); LCL about 1.4 times $\mathrm{CH}$. Rostrum long, with parallel margins, length about 2.5 times width, 0.45 times DCL (Fig. 6B-C). Eye about 0.4-0.5 times as long as rostrum; some ommatidia irregularly distributed on distal half or second third (Fig. 6C); inferior distal border slightly produced downwards.

AntENNAE. Antennule peduncle fourth article with anterior row of 9-10 simple setae and one distal robust seta (one preovigerous female with two) (Fig. 6D); antennular scale length 2.15-2.5 times width; flagellum with up to 10-11 articles. Antenna peduncle third article lateral margin with 4-5 proximal plumose setae and three distal thin long spine-like setae (Fig. 6E-F); flagellum with up to 12-14 articles (Fig. 6E).

Mouthparts. Mandibular palp second article with two simple setae: one simple seta on distal third and one simple slightly longer seta on lateral margin at mid-length; third article 1.15 times as long as second (Fig. 7A). Maxilla I palp well-developed, about six times as long as protopod (Fig. 7B). Maxilla II endopod proximal article about 1.6 times as long as distal; exopod as long as endopod first article (Fig. 7C).

Thoracopods. Endopod longer than exopod (Fig. 7D-E); endopod distal article slightly enlarged, with several (> 10) long setae; endopod segmentation weak. Thoracopod 8 epipod smaller than in other thoracopods and lacking setae (Fig. 7F).

Pleonites AND PLEOPODS. Pleonite IV epimeron posterolateral corner forming triangular proccess acutely pointed (Fig. 8C). Pleonites VI-VII posterodorsal border bearing distally rounded to slightly pointed denticles (Fig. 8F-G). Pleopod I protopod with long seta near base of exopod, reaching first half of exopod 'comb-row'; exopod about 0.7 times as long as protopod and endopod; lateral margin with 'comb-row' of about 25-30 bi-pectinate setae (Fig. 8A). Pleopods II-IV exopod with row of 4-6 smooth setae ('spine pairs') (Figs 6A, 8B). Pleopod IV protopod posterior border with 3(4?) serrations. Pleopod V distal article 4.0 times as long as wide, with five simple setae along distolateral and terminal margins, proximal-most the shortest (Fig. 8D). Pleopod VI 2.7 times as long as wide, with five simple setae along lateral and terminal margins, distal-most the longest (Fig. 8E). Pleopod V-VI pairs with acute triangular process between rami bases.

Anal SOMite, ANAl Plates AND UROPODS. Anal somite 1.15-1.4 times as long as pleonite VII. Anal plates acutely tapering distally, lacking distinct 'shoulder' (Fig. 8H). Uropods 1.15-1.28 times as long as pleonite VII+ anal somite (Fig. 6A); terminal seta two times as long as ramus. 


\section{Description of male}

TL 3.5-6.25 mm, RL 0.675-1.075 mm, DCL 1.375-2.425 mm, LCL 1.875-3.25 mm, CH 1.375$1.875 \mathrm{~mm}$. Carapace slightly longer than in females (Fig. 9A), LCL about 1.7 times CH. Ommatidia irregularly distributed along distal $2 / 3$ of eye (Fig. 9B). Antennular scale proportionally longer than in females (2.7-2.75 times as long as wide) (Fig. 9C); flagellum with up to 9-12 articles, thicker than in females. Antenna peduncle third article lateral margin with similar setation as in females; flagellum with

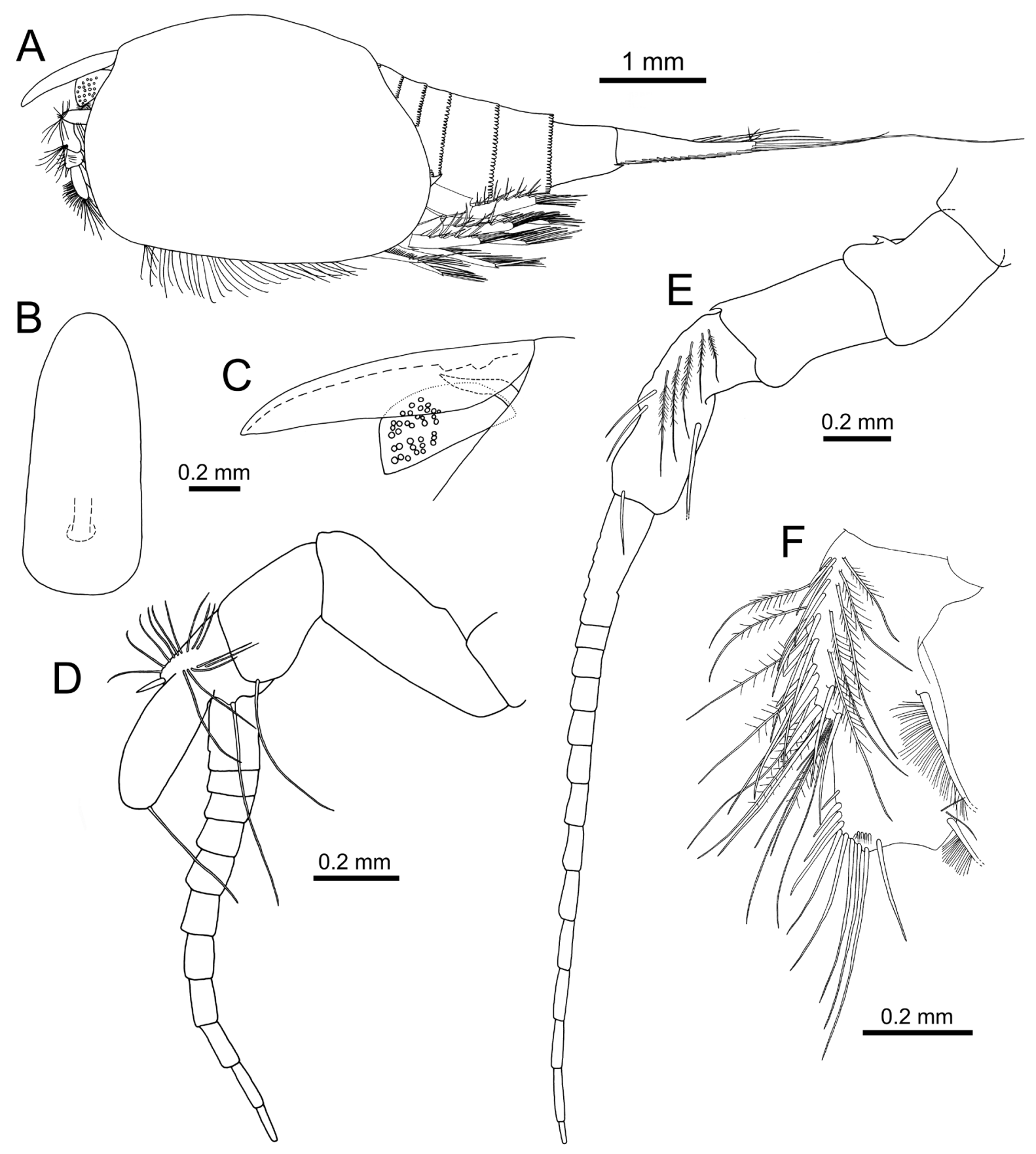

Fig. 6. Nebalia abyssicola Fage, 1929. Ovigerous female (DBUA0002350.01.A). A. Complete specimen, lateral view. B. Rostrum, dorsal view. C. Rostrum and eye, lateral view. D. Antennule, lateral view. E. Antenna, lateral view. F. Antenna, third article, lateral view. B-C: same scale bar; D-E: only selected setae illustrated. 
many articles ( $>40$ ) but not surpassing TL (Fig. 9D). Pleonites VI-VII denticles more pointed distally than in females. Pleopod IV protopod posterior border with four serrations. Small males $(<4.8 \mathrm{~mm}$ TL $)$ with uropods about as long as pleonite VII + anal somite; proportions in larger males (1.14-1.23) similar to females.
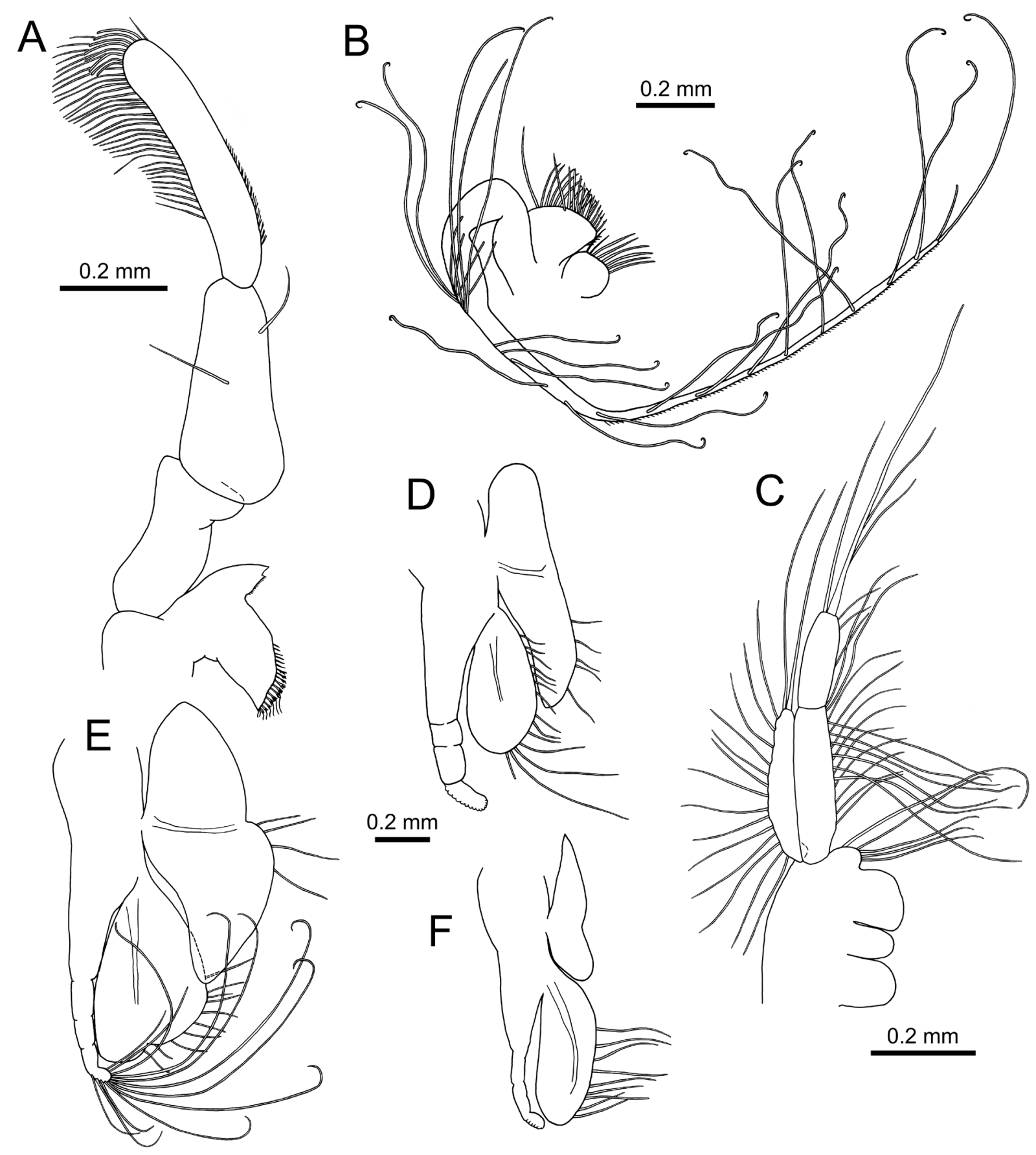

Fig. 7. Nebalia abyssicola Fage, 1929. Ovigerous female (DBUA0002350.01.A). A. Mandible. B. Maxilla I. C. Maxilla II. D. Thoracopod II. E. Thoracopod VII. F. Thoracopod VIII. C: setules and endites' setae not illustrated; D, F: endopod distal setae not illustrated; D-F: same scale bar. 


\section{Remarks}

Nebalia abyssicola is mostly characterized by the shape of the eye and the number and distribution of ommatidia, as discussed by Fage (1929), Ledoyer (1997) and Moreira et al. (2012). Fage (1929) also highlights the differences in setal armature of the fourth article of antennule, that includes one distal robust seta and a larger number of medial simple setae (up to 10) in comparison to other species of

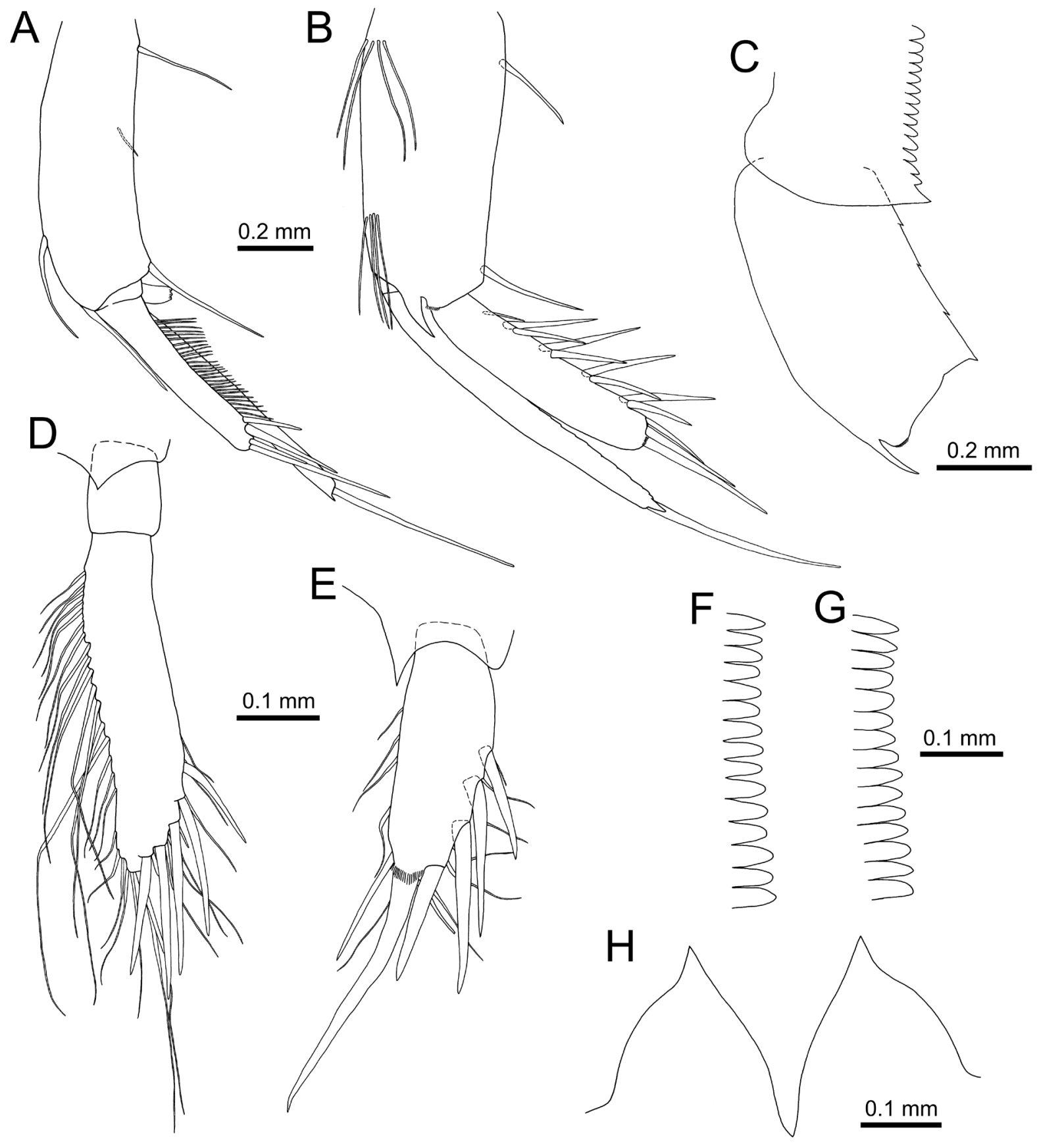

Fig. 8. Nebalia abyssicola Fage, 1929. Ovigerous female (DBUA0002350.01.A). A. Pleopod I, lateral view. B. Pleopod II, lateral view. C. Pleonite IV, epimeron and pleopod IV, protopod, lateral view. D. Pleopod V, ventral view. E. Pleopod VI, ventral view. F. Pleonite VI, dorsal and laterodorsal posterior border, denticles. G. Pleonite VII, dorsal and laterodorsal posterior border, denticles. H. Anal plates, ventral view. A-B, D-E, F-G: same scale bars; A-B: plumose setae not illustrated. 
similar body length, such as $N$. herbstii Leach, 1814, N. strausi and $N$. mediterranea Koçak \& Moreira, 2015, that bear 5-7 simple setae.

The specimens from the Gulf of Cadiz agree well with the full description of the species by Ledoyer (1997), including diagnostic characters such as eye features, antennular scale proportions, setae of the fourth article of antennule peduncle (one distal robust seta and row of 9-10 setae on anterior margin), proportions of the articles of the maxilla 2 endopod and exopod, and shape of pleonites 6-7 denticles. The second article of the mandibular palp is provided with two setae whereas Ledoyer (1997: fig. 1) only illustrates one; two setae are present as well in specimens from the Aegean Sea but the proximal seta is provided with short setules instead of being naked (Moreira et al. 2012: fig. 3A). Furthermore, one specimen had two robust setae on the fourth article of antennule peduncle instead of one as found in all other specimens and those reported elsewhere; such variation may occur, however, in other species as discussed above for $N$. strausi.

\section{Ecology}

This species has been reported at depths between 410 and $2368 \mathrm{~m}$; specimens from the Aegean Sea have been found in mud-clay sediments (Moreira et al. 2012). Specimens from MVs were found at depths of 354 to $1100 \mathrm{~m}$ in experimentally deployed wood and alfalfa substrata and associated with Gigantidas mauritanicus aggregations in cracks between large carbonate slabs at Darwin MV (1100 m depth).

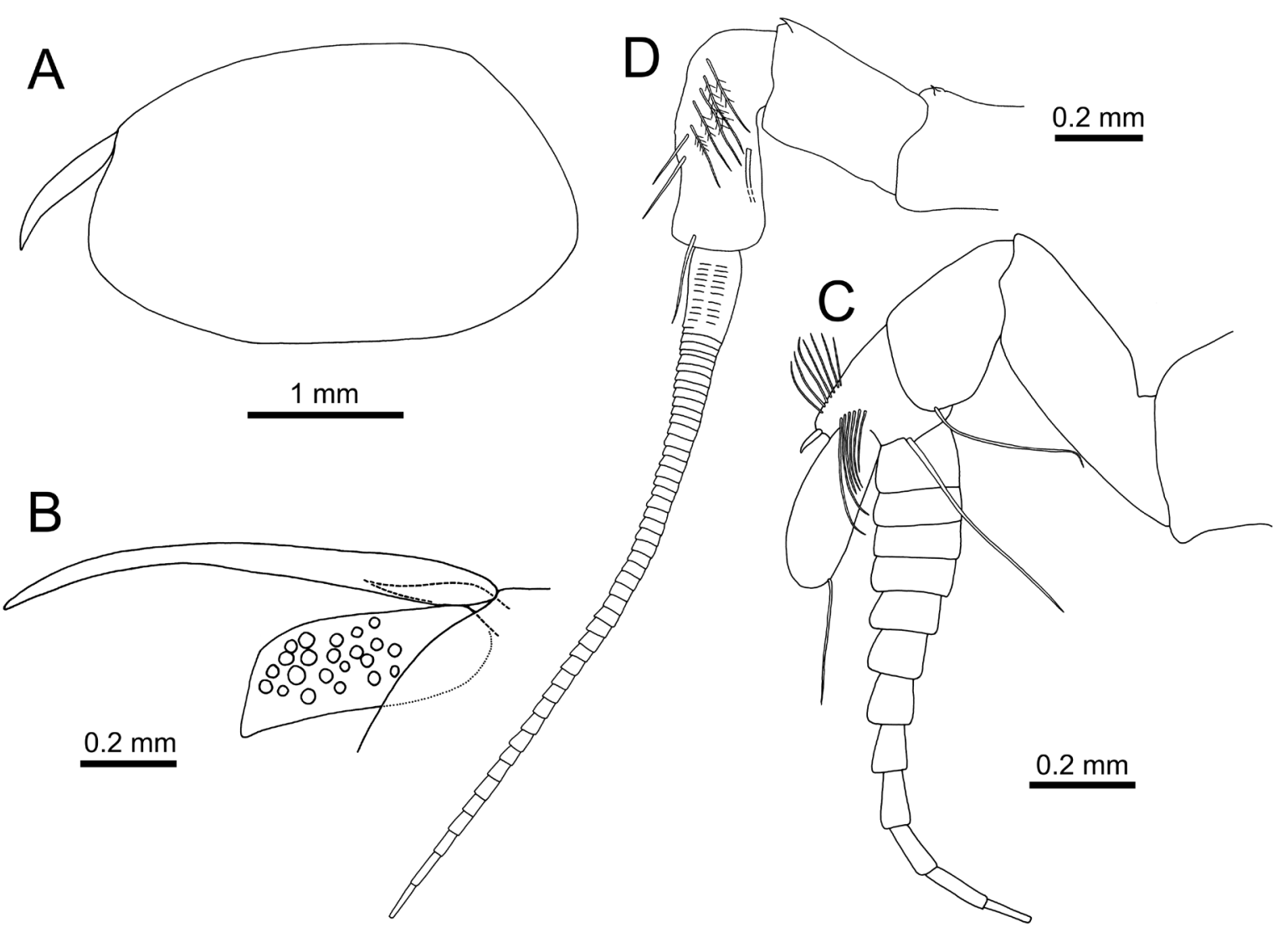

Fig. 9. Nebalia abyssicola Fage, 1929. Male (DBUA0001676.02.A). A. Rostrum and carapace, lateral view. B. Rostrum and eye, lateral view. C. Antennule, lateral view. D. Antenna, lateral view. C-D: only selected setae illustrated. 


\section{Distribution}

There are few records of this species; its known distribution ranges from the western Mediterranean (Monaco: Fage 1929; Corsica and Provence, France: Ledoyer 1997) and the Ionian Sea (Froglia 2010) to the Aegean Sea (Moreira et al. 2012). Darwin, Meknès and Mercator MVs, Moroccan continental slope, Gulf of Cadiz (Fig. 1); this is the first record for the Atlantic Ocean.

Genus Sarsinebalia Dahl, 1985

Sarsinebalia ledoyeri sp. nov. urn:lsid:zoobank.org:act:6203DB5B-D428-494D-AE12-96671063F37A

Figs 1, 10-16, Table 2

\section{Diagnosis}

Rostrum length 2.4-2.5 times width. Compound eye provided with 10-20 spaced ommatidia along distal half; pigment not observed; eye distal half with concave ventral margin; distal third gradually compressed laterally. Antennular scale length about 2.2 times width. Antennule peduncle fourth article with one distal robust seta. Antenna peduncle third article with 2-3 slightly plumose setae and three similar spine-like setae on lateral margin. Mandibular palp second article with two setae: 1) proximal seta on lateral surface, setulose along distal half inferior margin, about 0.5 times as long as article; 2) subdistal simple seta, longer than third article. Maxilla II endopod weakly segmented, distal article 1.8 times as long as proximal article; exopod 1.4 times as long as endopod proximal article. Pleonite IV epimeron posterolateral corner as triangular acute process. Pleonite IV posterolateral border with denticles distally acute; pleonites V-VII posterodorsal border with denticles distally rounded to pointed, never acutely produced. Pleopod I exopod lateral margin lacking setae. Pleopod IV protopod posterior border with three serrations; posterolateral corner acutely pointed. Uropods $0.7-0.85$ times as long as pleonite VII + anal somite.

\section{Etymology}

The new species is named after the French carcinologist Michel Ledoyer because of his many contributions to leptostracan taxonomy.

\section{Type material}

\section{Holotype}

MOROCCO • postovigerous +, TL $4.0 \mathrm{~mm}$, RL $0.675 \mathrm{~mm}$, DCL $1.65 \mathrm{~mm}$, LCL $2.15 \mathrm{~mm}$, CH $1.4 \mathrm{~mm}$; Gulf of Cadiz, Gemini MV; 35¹6.88' N, 06 $45.35^{\prime}$ W; 418 m depth; 6 Oct. 2006; St 64PE253_06, MV crater, mud breccia; MNCN 20.04/13706.

\footnotetext{
Allotype

MOROCCO • đ, TL 3.9 mm, RL 0.625 mm, DCL 1.6 mm, LCL 1.975 mm, CH $1.3 \mathrm{~mm}$; same locality and station as for holotype; MNCN 20.04/13707.

\section{Paratypes}

MOROCCO -4 postovigerous $q Q+$; same locality and station as for holotype; MNCN 20.04/13708 to 20.04/13711 10 preovigerous $9+$; same locality and station as for holotype; MNCN 20.04/13712 to 20.04/13721 - 6 o ; ; same locality and station as for holotype; MNCN 20.04/13722 to 20.04/13727 • 3 juveniles; same locality and station as for holotype; MNCN 20.04/13728 to 20.04/13730 • 4 postovigerous $+9+, 10$ preovigerous $+q+, 5 \hat{\jmath} \widehat{\lambda}, 3$ juveniles; same locality and station as for holotype; DBUA0002351.01.
} 


\section{Description of female}

Measurements. Postovigerous $q$ ? : TL 3.625-4.0 mm, RL 0.575-0.70 mm, DCL 1.50-1.75 mm, LCL 1.90-2.375 mm, CH 1.325-1.50 mm; preovigerous 우: TL 3.375-3.85 mm, RL 0.575-0.625 mm, DCL $1.125-1.60 \mathrm{~mm}$, LCL $1.625-2.075 \mathrm{~mm}, \mathrm{CH} 1.125-1.40 \mathrm{~mm}$.

CARAPACE, ROSTRUM AND EYE. Carapace roughly oval, margins convex or rounded, covering laterally most of pleonites III-IV (Fig. 10A); LCL about 1.5-1.6 times CH. Rostrum long, extending well beyond eyestalk, length 2.4-2.5 times width, $0.4-0.45$ times DCL (Fig. 10A, D); tapering gradually on distal half and turning downwards (Fig. 10B); paired ventral keels present; tip of rostrum provided with terminal spine, segmented proximally. Compound eye slightly longer than high, distal third becoming gradually compressed laterally (Fig. 10C); dorsal and distal margins almost straight, ventral margin straight proximally and concave on distal half (Fig. 10B); 10-20 spaced ommatidia, present mostly along distal half; pigmentation not observed in fixed specimens; supra-orbital plate with acute tip, reaching at least end of distal half of eye dorsal surface.

Antennule. Peduncle composed of four articles (Fig. 11A). First article shorter than second, naked. Second article widest at midpoint, length almost 3.0 times width, with (1) one plumose seta on anterior margin at mid-length, (2) cluster of about 12 smooth and plumose setae arising from posterolateral distal third surface, (3) cluster of about 10 short and long simple setae and one plumose seta on anterodistal

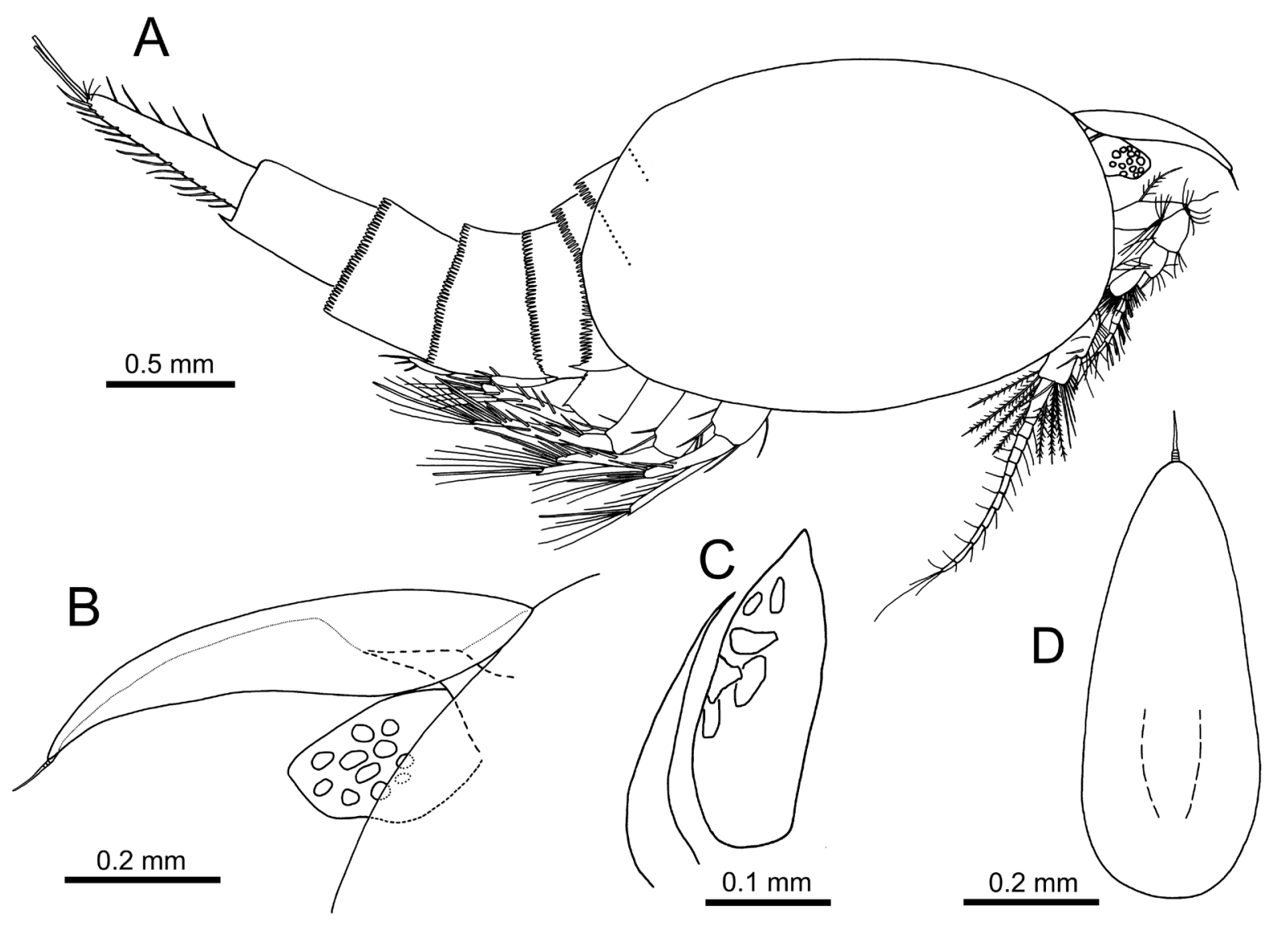

Fig. 10. Sarsinebalia ledoyeri sp. nov. Postovigerous females. A. Holotype (MNCN 20.04/13706). B-D. Paratypes (MNCN 20.04/13708, MNCN 20.04/13709). A. Complete specimen, lateral view. B. Rostrum and eye, lateral view. C. Eye and supra-orbital plate, ventral view. D. Rostrum, dorsal view. A: dashed lines marking distribution of denticles on posterior borders of pleonites II and III. 
margin. Third article 0.5 times as long as second, wider distally, with terminal cluster of about 12 simple setae on anterodistal and posterodistal margins, one long simple seta on external surface and two shorter setae on inner surface. Fourth article shorter than third, with (1) anterior row of 5-6 simple setae, (2) one distal robust seta, (3) lateral row of 2-3 simple setae on external surface, distal-most the longest,

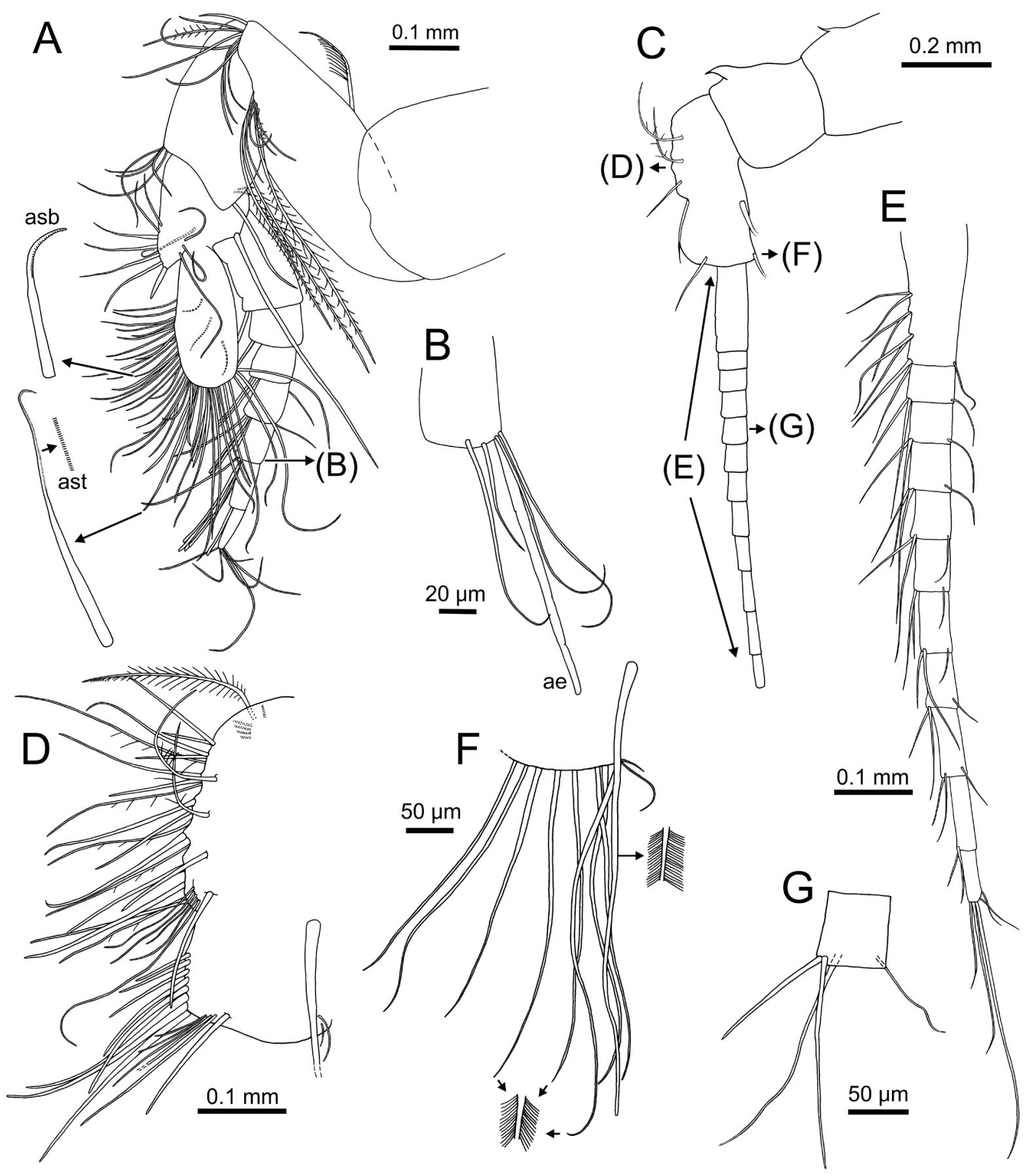

Fig. 11. Sarsinebalia ledoyeri sp. nov. Postovigerous female, paratype (MNCN 20.04/13708). A. Antennule, lateral view. B. Antennule, flagellum, fifth article. C. Antenna, lateral view, outline. D. Antenna, peduncle, third article, lateral view. E. Antenna, flagellum. F. Antenna, peduncle, third article, distal margin plumose setae. G. Antenna, flagellum, fifth article. A, C: letters in brackets refer to parts detailed in other drawings with same letters; B: only one aesthethasc out of five figured. 
(4) one simple seta on inner surface, (5) one simple seta arising from posterodistal margin, longer than article and antennular scale combined. Antennular scale roughly oval, length 2.2 times width; anterior margin slightly convex; anterior and terminal margins with (1) row of shorter setae recurved distally and provided with blunt teeth along distal half (asb in Fig. 11A), (2) numerous simple setae of different lengths with thinner teeth, setae arising from posteroterminal margin the longest (ast in Fig. 11A); row of three spaced simple setae on inner surface. Flagellum long, well-developed, shorter than peduncle, with 7 articles (6-7 in preovigerous females), proximal article as long as following three combined; each

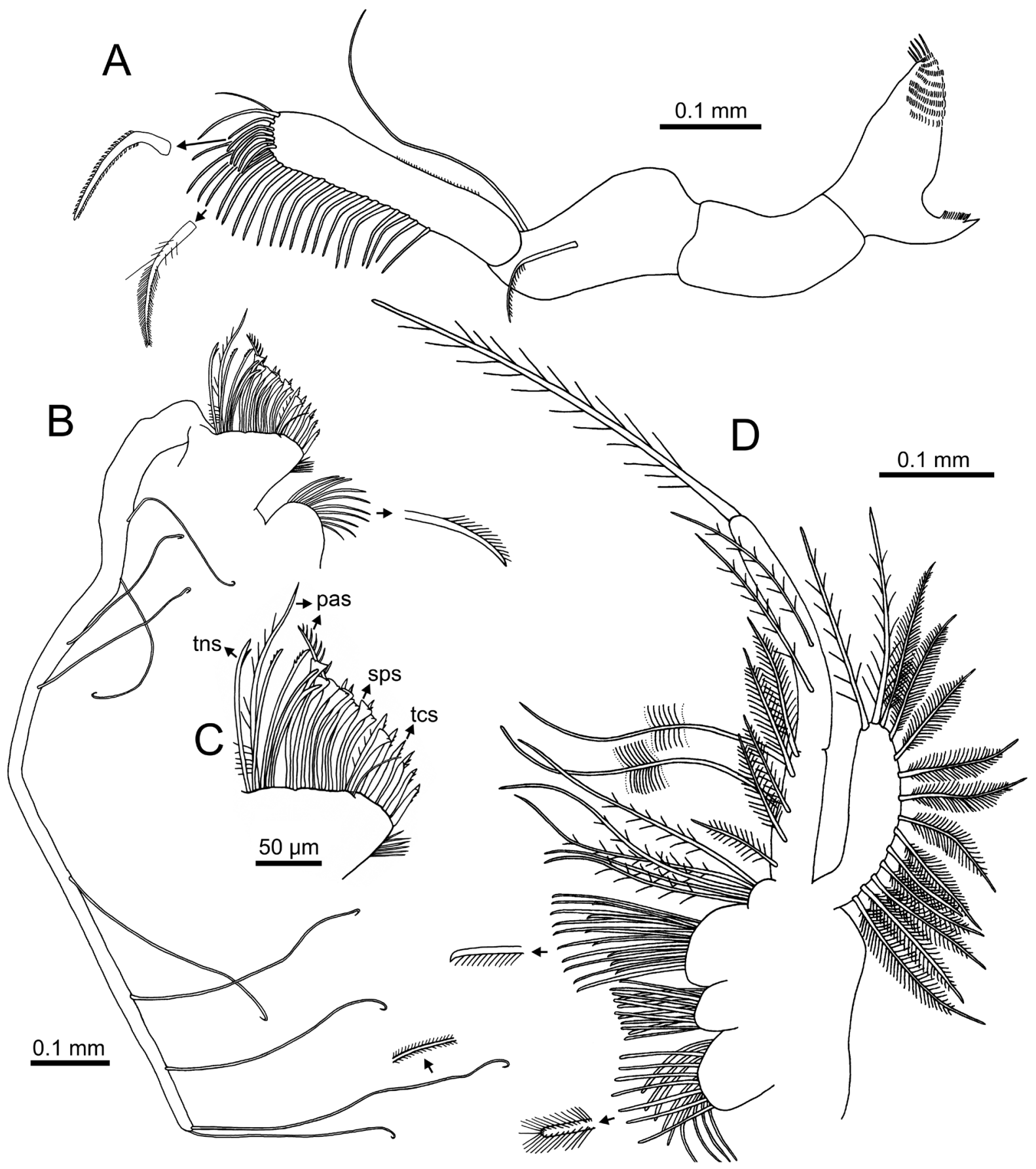

Fig. 12. Sarsinebalia ledoyeri sp. nov. Postovigerous female, paratype (MNCN 20.04/13708). A. Mandible. B. Maxilla I. C. Maxilla I, endites, detail. D. Maxilla II. 
article with (1) cluster of 2-8 aesthetascs and (2) 2-4 simple setae on distal margin (Fig. 11B), distal article with 5-6 setae and lacking aesthethascs.

Antenna. Peduncle composed of three articles (Fig. 11C). First article anterior margin with process ending in small acute spine. Second article about as long as first, anterior margin with subdistal acutely pointed process. Third article about 2.0 times as long as second; plumose seta arising proximally from inner surface, associated to four simple short setae; medial and lateral anterior margins with several rows of setae (Fig. 11D): (1) five sparsely plumose setae, (2) two rows of simple thin spine-like setae, of 5-6 setae each (most arranged in pairs), (3) five simple, thin setae, (4) terminal row of eight simple setae, increasing in length distally, (5) 2-3 slightly plumose setae and three spine-like similar setae along lateral margin, distal-most seta associated to 5-7 simple setae; posterior margin with long, densely plumose seta (Fig. 11F); cluster of 8-9 plumose setae along distal margin inner surface; posterodistal margin with two short simple setae of different length. Flagellum well-developed, composed of 11 articles (12 in one postovigerous female) (Fig. 11E); each article with four terminal setae, one shorter than others (Fig. 11G).

MANDiBle (Fig. 12A). Molar process well-developed, about as long as first palp article, with several rows of teeth on distal third and several distal simple setae; incisor process smaller, broadest basally, with row of acute teeth on medial margin and acute terminal process. Mandible palp composed of three articles; second article slightly longer than first, widest on proximal third; two setae: one at mid-length on lateral surface, setulose on inferior margin of distal half, about 0.5 times as long as article, and one subterminal simple seta, longer than third article. Third article 1.3 times as long as second, with almost parallel sides, slightly tapering distally; inferior margin with (1) a row of plumose setae extending from ending of proximal third to distal end, first four setae increasing gradually in length, (2) a row of six subdistal dentate setae, (3) two terminal setae, one as long as those of (1); superior margin proximal half with a row of minute setae.

MAXILLA I. First endite (proximal) with rounded medial margin bearing row of plumose setae (Fig. 12B). Second endite (distal) larger than first; inner margin with several distal simple setae; medial margin with several types of setae arranged in two rows: first row with (1) about 9 setae of increasing size with several teeth along distal half and one large tooth on distal superior margin (tcs in Fig. 12C) and (2) two pappose setae (pas in Fig. 12C); second row with (3) about ten spatulate setae (sps in Fig. 12C) and (4) six setae with several teeth (2-4) along distal superior margin, thinner than those of type (1) (tns in Fig. 12C); setae of types (1), (3) and (4) with one margin provided with long, spaced setules (Fig. 12C). Palp well-developed, about 4.0 times as long as protopod, with about 7-9 long setae along its entire length; setae provided with minute setules along distal third and with apex recurved distally (Fig. 12B).

Maxilla II (Fig. 12D). Protopod with four endites; first (proximal) and third endite the largest, fourth endite much shorter; first to third endites bearing numerous plumose setae arranged in two rows; fourth endite with five longer plumose setae. Endopod weakly segmented, longer than exopod, distal article 1.8 times as long as proximal; medial margin of both articles with one row of spaced plumose setae, proximal with two additional longer setae with long setules along distal half; distal article with one plumose seta, longer than endopod. Exopod 1.4 times as long as endopod proximal article; lateral margin with plumose setae, two distal-most setae as long as exopod.

THORACOPODS. Endopod longer than exopod, segmentation weak; with numerous plumose setae along anterior margin arranged in two rows and one long sparsely plumose seta (Fig. 13A); distal article expanded, in postovigerous females lacking long setae, in preovigerous females with several setae shorter than exopod (Fig. 13B-C). Exopod posterior margin with 6-9 plumose setae, 1-2 distal-most the longest (Fig. 13A). Epipod posterior margin with two plumose setae. Thoracopod VIII shorter than 
others, with epipod comparatively reduced and lacking setae (Fig. 13D); exopod posterior margin with about 5 plumose setae comparatively longer than those of other thoracopods.

Pleonites. Pleonite I posterior border lacking denticles. Pleonites II-VII bearing denticles along posterior border, at least dorsally and laterodorsally (Fig. 10A). Pleonite II with denticles along dorsal border and extending to dorsolateral border (Fig. 14A); denticles thin, distally acute. Pleonite III with denticles along dorsal border extending well into lateral border, ending at mid-length (Fig. 14B); denticles distally pointed with more or less parallel sides (dorsal) to triangular (laterodorsal). Pleonites IV-VII with posterior border fully provided with denticles. Pleonite IV with dorsal and dorsolateral denticles pointed to rounded becoming distally acute and triangular in shape along lateral border (Fig. 14C); epimeron posterolateral corner forming large tooth with triangular distal end, acutely pointed. Pleonites V-VII

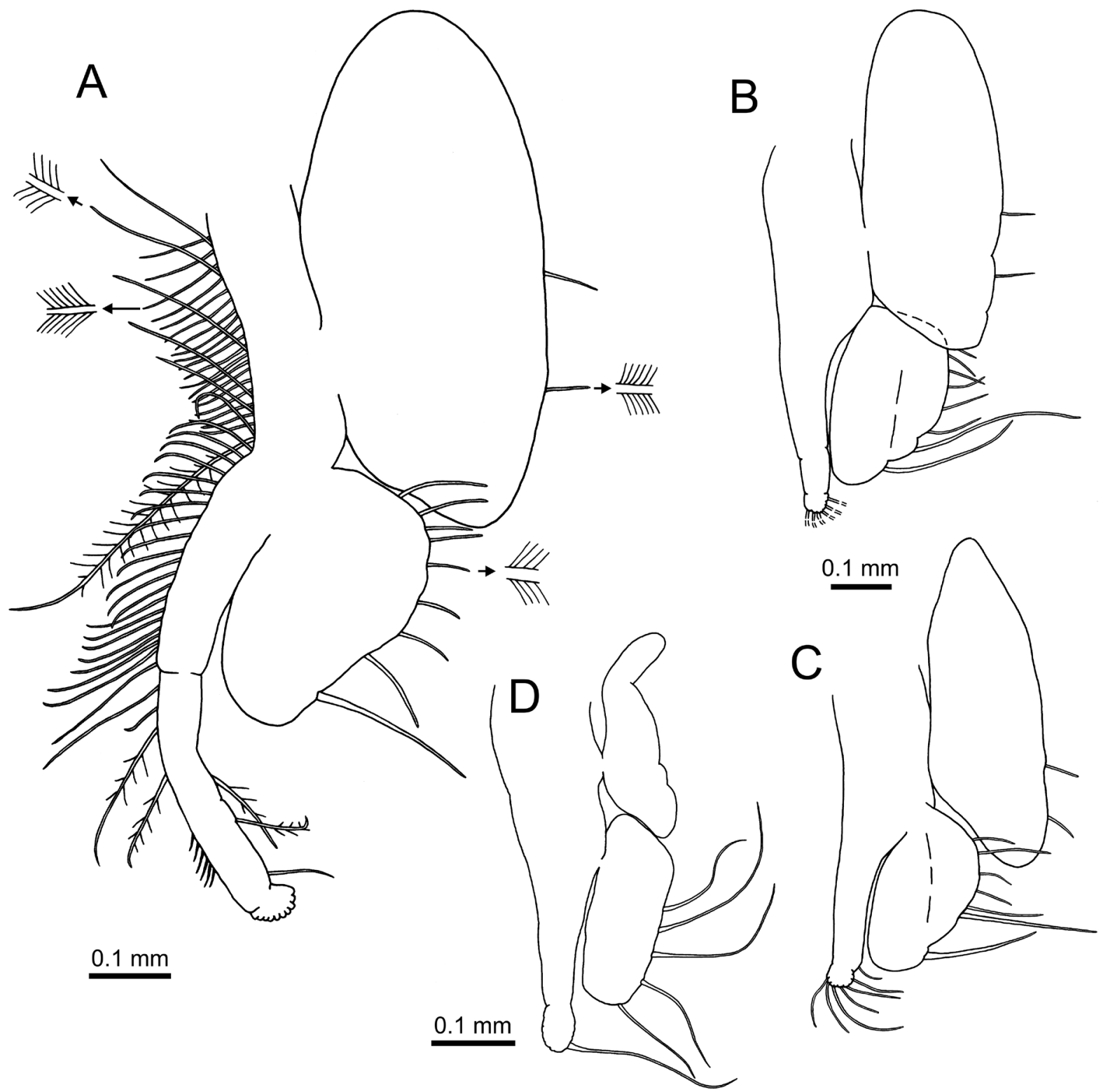

Fig. 13. Sarsinebalia ledoyeri sp. nov. Female, paratypes (MNCN 20.04/13708). A. Thoracopod III, showing setation. B. Thoracopod V. C. Thoracopod VII. D. Thoracopod VIII. A, D: postovigerous female; B-C: preovigerous female, same scale bar; B-D: only selected setae illustrated. 
dorsal and dorsolateral denticles similar in shape to those of pleonite III, distal end roughly pointed to rounded but never acutely produced (Fig. 14D-F); some denticles on ventrolateral border distally acute (Fig. 14D).

Pleopods 1-4. Pleopod 1 protopod with posterior margin even (Fig. 15A); with one short simple seta proximally on posterior margin and four distal simple setae: one seta on anterior margin arising subdistally and one seta between rami, posterior margin with long seta near exopod base and hardly reaching exopod distal half plus one shorter subdistal seta. Exopod about 0.6 times as long as protopod; lateral margin lacking 'comb-row'; distolateral margin with one short simple seta and four stout simple setaes, distal-most the longest; long plumose setae ( $>15)$ along medial margin. Endopod of two articles, 1.25 times as long as exopod; proximal article shorter, with appendix interna provided with three short recurved hooks; lateral and medial margins of distal article each with one row of $>10$ plumose setae, distal margin with acute process at apex and long, robust terminal seta.

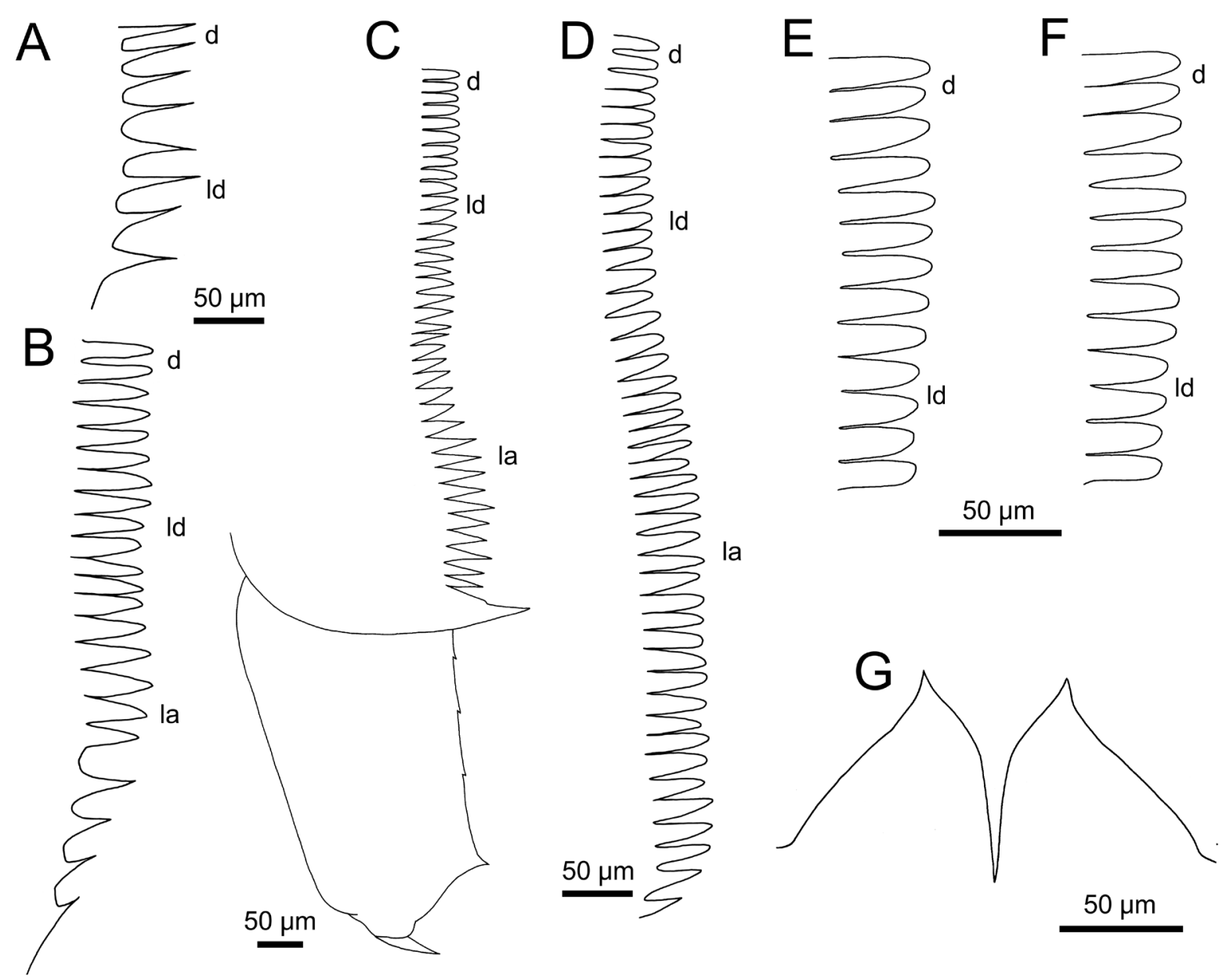

Fig. 14. Sarsinebalia ledoyeri sp. nov. Postovigerous female, paratype (MNCN 20.04/13708). A. Pleonite II, dorsal and laterodorsal posterior border, denticles. B. Pleonite III, dorsal and lateral posterior border, denticles. C. Pleonite IV (posterior border, denticles and epimeron) and pleopod IV (protopod), lateral view. D. Pleonite V, dorsal and lateral posterior border, denticles. E. Pleonite VI, dorsal and laterodorsal border, denticles. F. Pleonite VII, dorsal and laterodorsal border, denticles. G. Anal plates. A-B, E-F: same scale bars. 
Pleopods II-III. Similar in appearance. Protopod inner surface with 1-2 simple setae on proximal third, and cluster of 2-6 long simple setae at mid-length, posterior margin with cluster of three long simple setae on distal third, and two simple setae near rami bases: one near appendix interna and one thicker

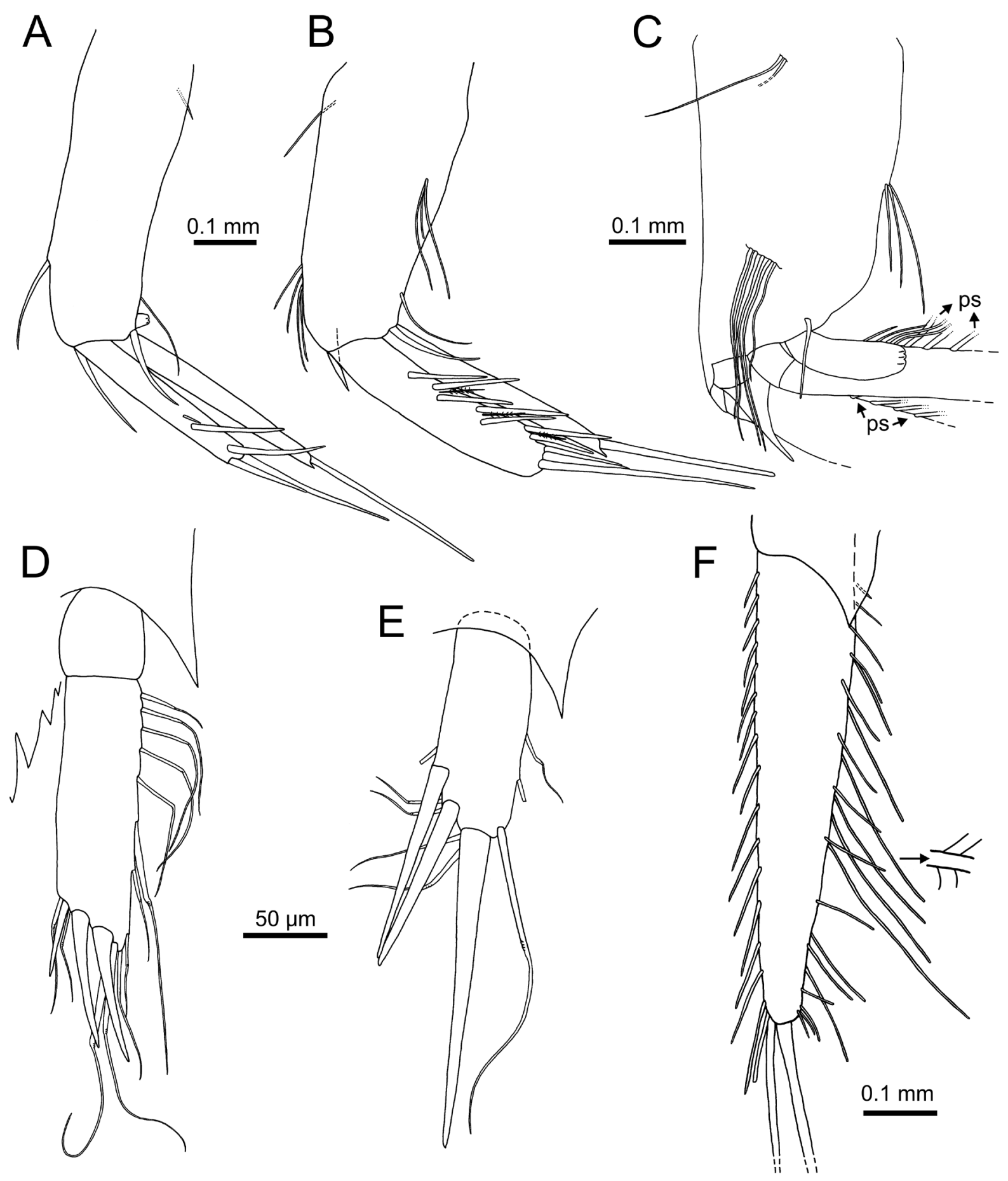

Fig. 15. Sarsinebalia ledoyeri sp. nov. Postovigerous female, paratype (MNCN 20.04/13708). A. Pleopod I, lateral view. B. Pleopod II, lateral view. C. Pleopod III, protopod and endopod appendix interna, inner side. D. Pleopod V, ventral view. E. Pleopod VI, ventral view. F. Right uropod, ventral view. A-B, D-E: same scale bars; A-B: plumose setae not illustrated; C: exopod and endopod plumose setose: setules not illustrated. 
seta close to exopod (Fig. 15B-C); acute triangular process between rami; posterior margin even. Exopod shorter than endopod; lateral margin with row of four smooth setae ('spine pairs'), each pair consisting of two setae subequal or one slightly shorter (sometimes one lacking in proximal pair), with short setulose seta in between; medial margin with about 10 long plumose setae; distal margin with three simple setae, distal-most the longest. Endopod of two articles; proximal article short, provided with appendix interna; lateral and medial margins of distal article each with one row of $>15$ plumose setae; terminal margin with one long, robust distal seta.

PleOPOD IV. Protopod posterior margin with three serrations (Fig. 14C); posterolateral corner acutely pointed. Rami similar to pleopods II-III.

Pleopods V-VI. Pleopod V-VI pairs with acute triangular process between rami bases. Pleopod V uniramous, length 4.3 times width, with three terminal stout simple setae, proximal-most much shorter (Fig. 15D); approximately 12-13 simple setae of different lengths along medial and terminal margins, appearing jointed at mid-length. Pleopod VI uniramous, length 3.0 times width (Fig. 15E); with three terminal simple setae, one longer than entire ramus; medial, distolateral and terminal margins with about eight 'jointed' setae of different lengths.

Anal somite, anal Plates AND UROPODS. Anal somite 1.15-1.35 times as long as pleonite VII (Fig. 10A). Anal plates with broad bases and acutely tapering distally (Fig. 14G); medial margins convex defining a Y-shaped invagination between plates; lateral margins gently sloping, lacking 'shoulder'. Uropods tapering distally, 0.7-0.85 times as long as pleonite VII+anal somite (Fig. 10A); lateral margin with 15-18 simple setae gradually increasing in length towards distal end; terminal margin with two longer robust setae, broken in all specimens but distal-most at least as long as uropods (Fig. 15F); medial margin with one row of simple setae similar to those on lateral margin but fewer and thinner plus one row of long plumose setae; distomedial margin with cluster of three short simple setae.
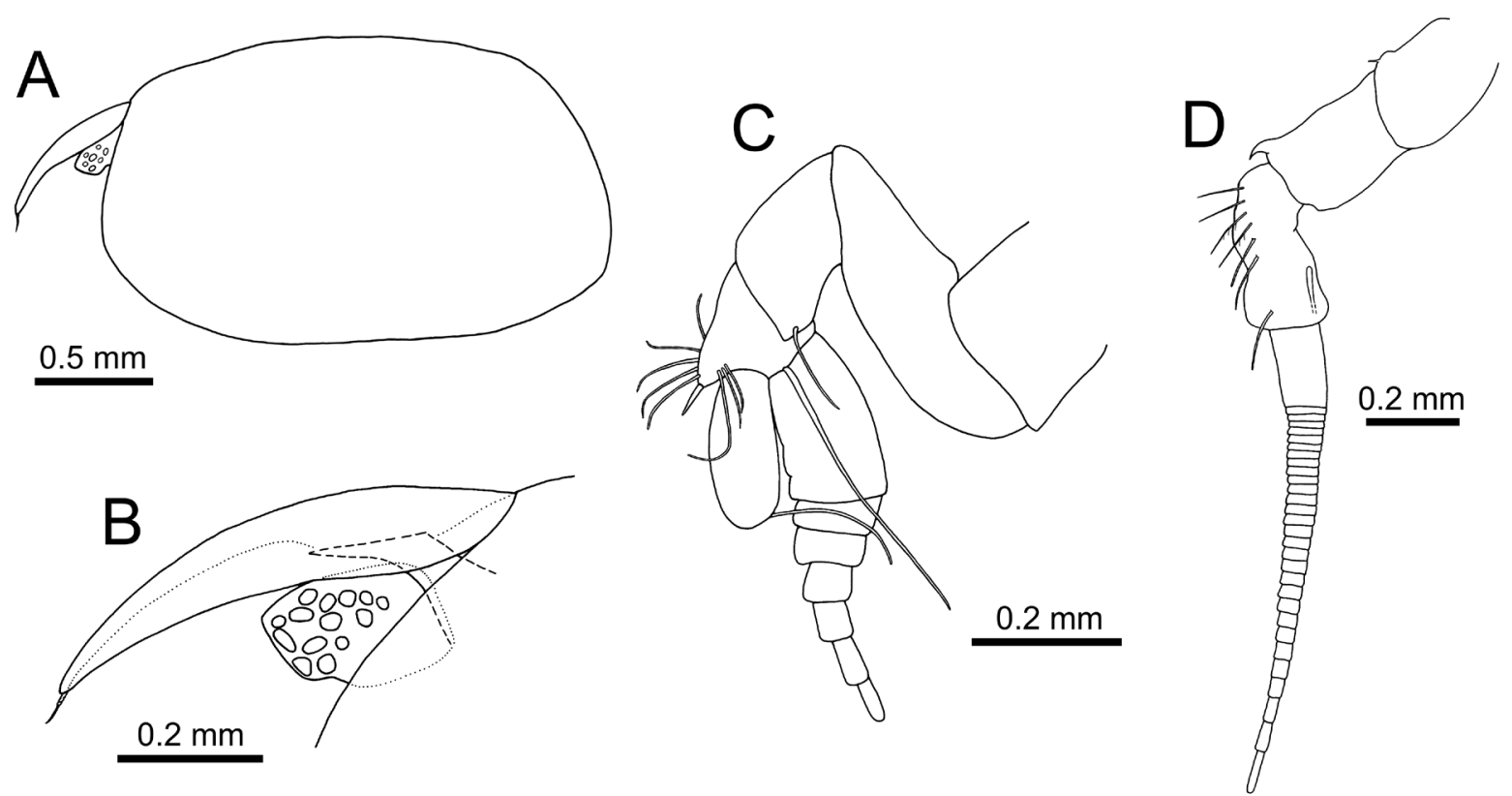

Fig. 16. Sarsinebalia ledoyeri sp. nov. Male. A. Allotype (MNCN 20.04/13707). B-D. Paratype (MNCN 20.04/13722). A. Rostrum, eye and carapace outline, lateral view. B. Rostrum and eye, lateral view. C. Antennule, lateral view. D. Antenna, lateral view. C-D: only selected setae illustrated. 


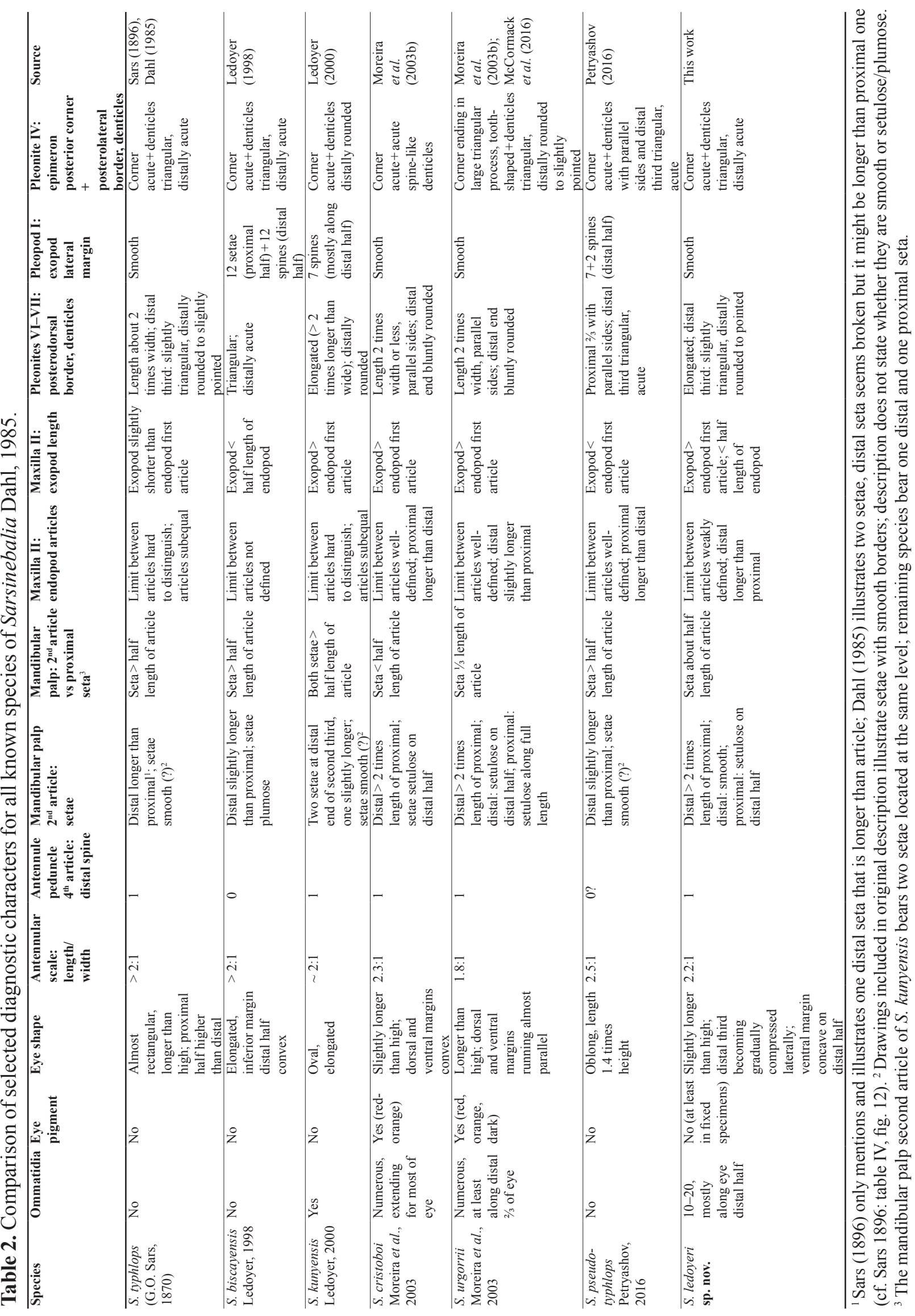




\section{Description of male}

TL 3.3-3.925 mm, RL 0.525-0.675 mm, DCL 1.275-1.675 mm, LCL 1.6-2.05 mm, CH 1-1.3 mm. Carapace proportions similar to females (Fig. 16A), LCL about 1.5-1.6 times CH. Ommatidia irregularly distributed along distal half or $2 / 3$ of eye (Fig. 16B). Antennular scale proportionally longer than in females (2.2-2.45 times as long as wide) (Fig. 16C); flagellum with up to 6-7 articles, thicker than in females. Antenna peduncle third article lateral margin with similar setation as in females; flagellum with many articles ( $>30$ ) but not surpassing TL (Fig. 16D). Pleopod IV protopod posterior margin with three serrations. Pleonites VI-VII denticles elongated, more pointed than in females.

\section{Remarks}

Known species of Sarsinebalia can be distinguished by whether or not eyes are provided with ommatidia/pigment and lateral margin of pleopod I exopod is provided with setae, as well as by the eye shape, features of maxilla II exopod and endopod and pleonites denticles (Table 2). Sarsinebalia ledoyeri sp. nov. is characterised by the following combination of characters: the rostrum is about 2.42.5 times as long as wide, the eye is provided with ommatidia (10-20) and lacks pigment, the eye is gradually compressed laterally along distal third and towards anterior margin, the eye ventral margin is concave along distal half, the antennular scale is about 2.2 times as long as wide, the second article of the mandibular palp bears one seta on lateral surface about 0.5 times as long as article and one subterminal seta longer than the third article, the distal article of the endopod of the maxilla II is about 1.8 times as long as the proximal article, the exopod of the maxilla II is clearly longer than the proximal article of the endopod, the posterodorsal border of pleonites VI-VII are provided with distally rounded to pointed denticles, the protopod of pleopod IV has three serrations along the posterior border and the posterolateral corner is acutely pointed, and the uropods are shorter than the pleonite VII and anal somite combined.

Sarsinebalia ledoyeri sp. nov. mainly differs from S. typhlops, S. biscayensis and S. pseudotyphlops in having eyes provided with ommatidia. Furthermore, S. typhlops also differs in that the two articles of the maxilla II endopod are subequal (Sars 1896: fig. 14), the proximal seta of the mandibular palp second article is more than two thirds of the length of the article whereas in S. ledoyeri sp. nov. is only half the length of the article, and the pleopod V-VI have more stout distal/distolateral setae according to Sars (1896) (V: 5, VI: 5 vs 3/3); S. typhlops also seems a larger species, reaching $9 \mathrm{~mm}$ in length (Sars 1896) whereas the largest mature specimens of $S$. ledoyeri sp. nov. only reach $4 \mathrm{~mm}$. In turn, S. biscayensis has elongated eyes, the fourth article of the antennule peduncle lacks the distal robust seta bearing instead one long simple seta similar to those along the medial margin, the pleopod I exopod is provided with 'spines' along the lateral border (as it happens in S. kunyensis Ledoyer, 2000 and S. pseudotyphlops) and the pleopod I protopod bears a row of simple, long setae along the proximal half of the posterior border instead of only one shorter seta (cf. Ledoyer 1998: fig. 2 vs Fig. 15A); S. pseudotyphlops has a comparatively longer antennular scale, the proximal article of the maxilla II endopod is longer than the distal one, the pleopod IV protopod has an even posterior margin and the posterodorsal denticles of pleonites VI-VII are acute distally. On the other hand, S. kunyensis is also provided with ommatidia but differs from S. ledoyeri sp. nov. in having oval elongated eyes, the two articles of the maxilla II endopod are subequal, the proximal seta of the mandibular palp second article is comparatively longer and the denticles along the lateral border of the pleonite IV epimeron are distally rounded instead of being acute. Sarsinebalia ledoyeri sp. nov. differs from the shallow-water species, S. cristoboi and S. urgorrii, in lacking eye pigment and in the shape of the eyes, that has distal and ventral margins parallel in S. urgorrii and convex in S. cristoboi; the aforementioned species also bear proportionally shorter denticles along posterodorsal borders of pleonites VI-VII that are always distally rounded, the distal long seta of the mandibular palp second article bears short setules along distal half instead of being naked, and the proximal article of the maxilla II endopod is longer than the distal one in S. cristoboi while the distal 
article is, in turn, only slightly longer in S. urgorrii. Finally, the description of S. typhlops occidentalis is brief but it shows that the rostrum is wider basally than that of $S$. ledoyeri sp. nov. and the furca is about as long as the pleonite VII and the anal somite combined instead of the former being clearly shorter; Hessler \& Sanders (1965) also mention that the mandible is provided with "two large setae on second segment of palp" whereas in Sarsinebalia ledoyeri sp. nov. the length of the proximal seta is about one third of the distal one.

On the other hand, S. typhlops has been previously recorded in the Mediterranean at deep-sea depths (Lo Bianco 1903). Ledoyer (1997) also reports S. typhlops from southern France in Posidonia beds at a shallow depth $(11 \mathrm{~m})$; the only examined specimen corresponded to one ovigerous female but this mostly differs from the description by Dahl (1985) in having eyes that are provided with many ommatidia (ca 40 each), the maxilla II has an endopod with the two articles clearly defined, the distal one being slightly longer than the proximal, and the maxilla II exopod is clearly longer than the proximal article of the endopod. In fact, this description fits better with that of $S$. urgorrii, that is mostly present in shallow waters as well; the shape of the eyes and the denticulation of pleonite IV epimeron, as illustrated by Ledoyer (1997) is also very similar to that of S. urgorrii (cf. Ledoyer 1997: fig. 5 and Moreira et al. 2003b: figs $8 \mathrm{f}$ and 14g). Therefore, previous records of $S$. typhlops in shallow waters and into the Mediterranean might correspond to other taxa and deserve further revision (McCormack et al. 2016; Latry \& Droual 2020).

\section{Ecology}

This species was collected from the crater of the Gemini MV and was the most abundant species in a box core sample. The sediments (mud breccia) yielded a highly diverse macrofaunal assemblage (ca 50 species) characterized by the presence of mega-epifauna (Pennatulacea, Hydrozoans, Crinoids), the chemosymbiotic species Siboglinum spIb (as in Hilário et al. 2010), and numerous species of peracarid crustaceans.

\section{Distribution}

Only known from the type locality, Gemini MV (418 m depth), in the Moroccan margin of the Gulf of Cadiz (this study; Fig. 1).

\section{Discussion}

\section{Taxonomy of Sarsinebalia Dahl, 1985}

McCormack et al. (2016) recently reviewed the characters considered diagnostic for Sarsinebalia and concluded that further work is needed to assess the validity of the genus, including a molecular approach. Nevertheless, the new species described here was tentatively included in Sarsinebalia mostly because it has a rostrum with subterminal spine and it lacks a 'comb-row' of bi-pectinate setae on the lateral margin of the pleopod I exopod (sensu Walker-Smith 2000); such setae are present instead in Nebalia, Dahlella Hessler, 1984, Paranebalia and Levinebalia Walker-Smith, 2000 (Haney \& Martin 2004). However, some species of Sarsinebalia bear a pleopod I exopod that is provided with setae along lateral margin (Table 2); furthermore, some are simple while other setae are provided with lateral ornamentation as in S. biscayensis and S. kunyensis ("finement ciliées", cf. Ledoyer 2000: 66) but with simple distal tip ("les épines sont apparemment simples et non barbelées et trifides", cf. Ledoyer 1998: 32). On the contrary, bi-pectinate setae of pleopod I 'comb-row' in species of Nebalia are usually described as laterally serrated and ending in a tridentate tip, composed by a bifid, stout apex flanked by two distally-acute sinuous processes (e.g., Dahl 1985; Martin et al. 1996; Olesen 1999; Moreira et al. 2003b, 2007, 2009a; Haney \& Martin 2005; Koçak \& Moreira 2015; Othman et al. 2016). Therefore, as stated by McCormack et al. (2016), species of Sarsinebalia nowadays seem only united by bearing a rostrum with subterminal spine, a character that is also shared with other genera, and this lack of synapomorphies challenges 
the validity of the genus (see Walker-Smith \& Poore 2001). However, the possibility of sharing other diagnostic characters that have not yet been fully evaluated cannot be ruled out (McCormack et al. 2016). For example, species of Sarsinebalia seem to differ from Nebalia in the appearance of the setae on the mandibular palp although there is a lack of accurate descriptions for some species of each genus. Thus, the second article is provided in Sarsinebalia with two setae: one can be much longer than the other and the article as well (S. typhlops - but see also Table 2 -, S. cristoboi, S. urgorrii, Sarsinebalia ledoyeri sp. nov.) or, alternatively, both are similar in length but if so, they are at least longer than half the length of the article (S. biscayensis, S. kunyensis, S. pseudotyphlops). Species of Nebalia usually bear two setae, one shorter than the other or as long as each other, being both shorter than half the length of the article (e.g., N. strausi, N. brucei Olesen, 1999, N. gerkenae Haney \& Martin, 2000, N. kocatasi Moreira, Koçak \& Katagan, 2007, N. deborahae Bochert \& Zettler, 2012, N. terazakii Othman, Toda \& Kikuchi, 2016); some species bear instead one seta (N. lagartensis Escobar-Briones \& VillalobosHiriart, 1995, N. hessleri Martin, Vetter \& Cash-Clark, 1996) or three setae (N. marerubri Wägele, 1983, $N$. cannoni Dahl, 1990) but in any case not longer than the second article. The exception to this apparent pattern are those species of Nebalia with eyes provided with distal lobes namely $N$. daytoni Vetter, 1996, N. daytoni brevicaudata Ledoyer, 2000 and N. schizophthalma Haney, Hessler \& Martin, 2001, that show a similar pattern to that of Sarsinebalia. Regarding the third mandibular palp article, there is one row of setae along the inferior margin that might subtly differ between Sarsinebalia and Nebalia; thus, the first few proximal setae in Nebalia seem much shorter than the others (Figs 3A, 7A) while in Sarsinebalia there seems to be a gradual increase in length (S. cristoboi, S. urgorrii) or no difference at all (Fig. 12A); again, the lack of accurate or explicit descriptions in many taxa prevents at the moment further generalization.

In any case, it seems that detailed studies of patterns of setation in antennae and mouthparts of leptostracans might eventually reveal whether they may have a taxonomic value or, alternatively, being related to trophic strategy. In fact, SEM examination of such appendages has shown a high variety of setal ornamentation (e.g., Martin et al. 1996) and, for instance, Moreira et al. (2009a: fig. 1C, F) showed that the denticulation of some equivalent setae in the third peduncle article of the antenna differ between the sympatric $S$. cristoboi and $S$. urgorrii that, in turn, seem to show a spatial segregation related to sedimentary features.

\section{Bathymetric distribution and mud volcanoes}

Most of the extant leptostracans are known from depths usually shallower than $100 \mathrm{~m}$ (Haney \& Martin 2016), including members of Nebalia, Nebaliella, Dahlella, Sarsinebalia and Levinebalia; the three known species of Paranebalia and the only representant of Saronebalia Haney \& Martin, 2004 are apparently restricted to shallow waters, including soft-bottoms colonised by seagrasses and macroalgae (e.g., Modlin 1991; Ledoyer 2000; Haney \& Martin 2004; Roccatagliata et al. 2010; Song et al. 2012a). Some leptostracans have been reported from bathyal depths down to $3000 \mathrm{~m}$, such as Dahlella caldariensis Hessler, 1984 (2490-2620 m depth), Nebaliella caboti Clark, 1932 (378-2900 m depth), Nebaliella declivatas Walker-Smith, 1998 (down to $1840 \mathrm{~m}$ ), Nebalia abyssicola (410-2368 m depth), Nebalia schizophthalma (2886 m depth) and S. biscayensis (2100-2167 m depth) (Hessler 1984; Ledoyer 1998; Walker-Smith 1998; Haney et al. 2001). At the moment, the only two known species reaching greater depths are Nebaliella kurila Petryashov, 2016 and S. pseudotyphlops that were described from specimens collected at depths well below 5000 m near the Kuril-Kamchatka Trench (Petryashov 2016). On the other hand, $S$. typhlops has been reported from a wide depth range, with records from the continental shelf(90-250 m depth: Vader 1973; Dahl 1985) to depths of ca $2000 \mathrm{~m}$ (Mauchline \& Gage 1983). However, as mentioned above, it is likely that some records of this species might refer to other species described after Dahl's review of European leptostracans (Dahl 1985); a review of past records would therefore be desirable to assess the actual geographic and bathymetric distribution of S. typhlops (Koçak et al. 2011; McCormack et al. 2016; Latry \& Droual 2020). 
To our knowledge, leptostracans were previously reported from mud volcanoes only by Ritt et al. (2012) who mentions the occurrence of undetermined Leptostraca in reduced sediments from Amon and Cheops MVs (1000 and $3007 \mathrm{~m}$ depth, respectively; Nile Deep-sea Fan, Eastern Mediterranean Sea). The three species reported here from MVs at the Moroccan margin of the Gulf of Cadiz constitute the first record of leptostracans at species level in this kind of environment, also showing apparent differences in their bathymetric distribution. Sarsinebalia ledoyeri sp. nov. was collected only from mud volcano sediments at 418 m depth in the Gemini MV in 2006, while the two species of Nebalia were collected in association with experimentally deployed organic substrates. Thus, $N$. abyssicola was present in all three MVs where colonization experiments were deployed (Darwin, Meknès and Mercator). It was found both inside and outside the net enclosing the organic substrates and showed the widest range in depth as expected (354-1100 m). The presence of $N$. strausi in a deep-sea MV was, however, unexpected. Although this species has been recorded at depths of $140 \mathrm{~m}$ (Moreira et al. 2009b), it is usually reported from the shallow subtidal (Dahl 1985; McCormack et al. 2016) reaching high abundances in Zostera meadows (Moreira et al. 2004). The presence of this species at greater depths (Mercator MV, $354 \mathrm{~m}$ ) may be explained by the attraction of specimens from shallower bottoms to eventual accumulation of organic matter at the top of the MV; this would allow for specimens to colonise the CHEMECOLI units filled with organic substrates deployed in the experiment developed in 2007-2009. In fact, the units deployed in the shallower and closer to coast Mercator MV showed higher rates of colonization by typical organic-fall species (e.g., opportunist scavengers feeding on phytodetritus) than the ones deployed at deeper MVs (Cunha et al. 2013a). Some leptostracans are known to reach high abundances in areas where dead macroalgae are deposited (Martin et al. 1996) and are also attracted to baited traps (Lee \& Morton 2004; Morton \& Lee 2012) while other species do not respond to organic enrichment (Vetter 1996a). Indeed, N. strausi may feed on accumulations of dead leaves of P. oceanica (François et al. 2018) and is considered to behave as an opportunistic species responding positively to organicallyenriched sediments below cages for fish farming (Tomassetti et al. 2016). On the other hand, specimens of $N$. strausi found on the MV corresponded only to inmature males and preovigerous females. Lee \& Morton (2005) highlighted that specimens of Nebalia mortoni Lee \& Bamber, 2011 (as Nebalia sp.) were differently attracted to baited traps depending of the life-cycle stage; for instance, mature males were never found in traps while immature specimens (non-ovigerous females) constituted about $80 \%$ of the leptostracan catch being ovigerous and post-ovigerous females collected in fewer numbers. Finally, $N$. strausi was only found in the first sampling, that occurred after 290 days of units deployment but not in a second sampling of the colonization sets at Mercator MV that was carried out after almost two years. Except for one juvenile (washed from the net) the specimens were all found inside the net enclosing the organic substrates; this would suggest that $N$. strausi was present in the experimental units as long as the organic substrate (alfalfa) remained or that the juveniles that settled on the decaying organic substrates could not survive to maturity inside the net ( $2 \mathrm{~mm}$ mesh size) that enclosed the deployed substrates. In fact, the scavenging lyssianasid Orchomene grimaldii Chevreux, 1890 was also found on such units after one year but not in samples collected after two years when most of the alfalfa had disappeared or been consumed (Cunha et al. 2013a). On the contrary, $N$. abyssicola was found at the three MVs in samples recovered both after 1 and 2 years. Ovigerous females (with small juveniles in their brood pouches) were only found in Darwin MV and were all collected from the external components of the colonization unit; inside the net enclosing the organic substrates only smaller specimens (juveniles, preovigerous females and males) were found. Furthermore, N. abyssicola was also collected from Gigantidas mauritanicus aggregations at the experimental site in Darwin MV just after the deployment of the CHEMECOLI units, and a couple of weeks after that; this suggests that the species is usually present in this habitat and might rely on other food sources as well.

In any case, more sampling in MVs is needed to test whether there is a regular presence in MVs of the deep-sea species $N$. abyssicola, if $N$. strausi is an occasional visitor of shallow MVs when attracted by organic accumulations, and to assess what is the actual pattern of geographic and bathymetric distribution of Sarsinebalia ledoyeri sp. nov. 


\section{Acknowledgements}

The authors are grateful to chief scientists and participants of the cruises M2006 (64PE253), onboard RV Pelagia (boxcore samples on Gemini MV), JC10, onboard RRS James Cook (ROV suction samples, deployment of colonization experiments), 64PE284, onboard RV Pelagia (deployment and recovery of colonization experiments) and B09-14b, onboard RV Belgica (recovery of colonization experiments). Samples were obtained in the framework of the projects CHEMECO (European Science Foundation - EURODEEP; FCT - EURODEEP/0001/2007), HERMES (EC contract number GOCE-CT-511234; European Commission's Framework Sixth Programme), HERMIONE (contract ENV/2008/1/226354, European Commission's Framework Seventh Programme) and MiCROSYSTEMS (European Science Foundation - EuroDIVERSITY). Thanks are due to FCT/MCTES for the financial support to CESAM (UIDP/50017/2020+UIDB/50017/2020), through national funds. P. Esquete is funded by national funds (OE), through FCT - Fundação para a Ciência e a Tecnologia, I.P., in the scope of the framework contract foreseen in the numbers 4, 5 and 6 of the article 23, of the Decree-Law 57/2016, of August 29, changed by Law 57/2017, of July 19. We are also grateful to Begoña Sánchez (MNCN, Madrid) for her help with deposit of type specimens. Constructive and detailed comments from two anonymous reviewers are greatly appreciated.

\section{References}

Bochert R. \& Zettler M.L. 2012. Nebalia deborahae, a new species of Leptostraca (Phyllocarida) from South West Africa. Crustaceana 85: 205-218. https://doi.org/10.1163/156854012X623782

Cunha M.R., Matos F.L., Génio L., Hilário A., Moura C.J., Ravara A. \& Rodrigues C.F. 2013a. Are organic falls bridging reduced environments in the deep sea? - Results from colonization experiments in the Gulf of Cádiz. PLoS One 8 (10): e76688. https://doi.org/10.1371/journal.pone.0076688

Cunha M.R., Rodrigues C.F., Génio L., Hilário A., Ravara A. \& Pfannkuche O. 2013b. Macrofaunal assemblages from mud volcanoes in the Gulf of Cadiz: abundance, biodiversity and diversity partitioning across spatial scales. Biogeosciences 10: 2553-2568. https://doi.org/10.5194/bg-10-2553-2013

Dahl E. 1985. Crustacea Leptostraca, principles of taxonomy and a revision of European shelf species. Sarsia 70: 135-165. https://doi.org/10.1080/00364827.1985.10420626

de Haas H. \& Shipboard Scientific Party. 2006. Seismic and Sedimentological Investigations of the Carbonate Mounds and Mud Volcanoes at the Pen Duick Escarpment and SE Gulf of Cadiz. Cruise report R.V. Pelagia cruise M2006 (64PE253).

Escobar-Briones E. \& Villalobos-Hiriart J.L. 1995. Nebalia lagartensis (Leptostraca) a new species from the Yucatán Peninsula, Mexico. Crustaceana 68: 1-11. https://doi.org/10.1163/156854095X00322

Fage L. 1929. Cumacés et Leptostracés provenant des Campagnes Scientifiques du Prince Albert ${ }^{\text {er }}$ de Monaco. Résultats des Campagnes scientifiques accomplies sur son Yacht par Prince Albert I Ir 77: 1-50.

François R., Mascart T., De Troch M., Loïc M. \& Lepoint G. 2018. Seagrass organic matter transfer in Posidonia oceanica macrophytodetritus accumulations. Estuarine, Coastal and Shelf Science 212: 73-79. https://doi.org/10.1016/j.ecss.2018.07.001

Froglia C. 2010. Crustacea, Phyllocarida, Leptostraca. Biologia Marina Mediterranea 17 (Suppl. 1): 471.

Gaudron S.M., Pradillon F., Pailleret M., Duperron S., Le Bris N. \& Gaill F. 2010. Colonization of organic substrates deployed in deep-sea reducing habitats by symbiotic species and associated fauna. Marine Environmental Research 70: 1-12. https://doi.org/10.1016/j.marenvres.2010.02.002. 
Génio L., Johnson S.B., Vrijenhoek R.C., Cunha M.R., Tyler P.A., Kiel S. \& Little C.T.S. 2008. New record of "Bathymodiolus" mauritanicus Cosel from Gulf of Cadiz (NE Atlantic) mud volcanoes. Journal of Shellfish Research 27 (1): 53-61. https://doi.org/10.2983/0730-8000(2008)27[53:NROBMC]2.0.CO;2

González-García E., Mateo-Ramírez A., Urra J., Farias C., Marina P., Lozano P., López-González P.J., Megina C., García Raso J.E., Gofas S., López E., Moreira J., López-González N., SánchezLeal R.F., Fernández-Salas L.M. \& Rueda J.L. 2020. Composition, structure and distribution of epibenthic communities within a mud volcano field of the northern Gulf of Cádiz in relation to environmental variables and trawling activity. Journal of Sea Research 160-161: 101892. https://doi.org/10.1016/j.seares.2020.101892

Haney T.A. \& Martin J.W. 2000. Nebalia gerkenae, a new species of leptostracan (Crustacea: Malacostraca: Phyllocarida) from Bennett Slough region of Monterey Bay, California. Proceedings of the Biological Society of Washington 113 (4): 996-1014.

Haney T.A. \& Martin J.W. 2004. A new genus and species of leptostracan (Crustacea: Malacostraca: Phyllocarida) from Guana Island, British Virgin Islands, and a review of leptostracan genera. Journal of Natural History 38: 447-469. https://doi.org/10.1080/0022293021000033210

Haney T.A. \& Martin J.W. 2005. Nebalia kensleyi, a new species of leptostracan (Crustacea: Phyllocarida) from Tomales Bay, California. Proceedings of the Biological Society of Washington 118 (1): 3-20. https://doi.org/10.2988/0006-324X(2005)118[3:NKANSO]2.0.CO;2

Haney T.A. \& Martin J.W. 2016. Collecting and processing leptostracans. Journal of Crustacean Biology 36: 837-840. https://doi.org/10.1163/1937240X-00002485

Haney T.A., Hessler R.R. \& Martin J.W. 2001. Nebalia schizophthalma, a new species of leptostracan (Malacostraca) from deep waters off the east coast of the United States. Journal of Crustacean Biology 21: 192-201. https://doi.org/10.1651/0278-0372(2001)021[0192:NSANSO]2.0.CO;2

Hessler R.R. 1984. Dahlella caldariensis, new genus, new species: a leptostracan (Crustacea, Malacostraca) from deep-sea hydrothermal vents. Journal of Crustacean Biology 4: 655-664.

Hessler R.R. \& Sanders H.L. 1965. Bathyal Leptostraca from the continental slope of the northeastern United States. Crustaceana 9 (1): 71-74. https://doi.org/10.1163/156854065X00190

Hilário A., Johnson S.B., Cunha M.R. \& Vrijenhoek R.C. 2010. High diversity of frenulates (Polychaeta: Siboglinidae) in the Gulf of Cadiz mud volcanoes: a DNA taxonomy analysis. Deep Sea Research I 57: 143-150. https://doi.org/10.1016/j.dsr.2009.10.004

Koçak C. \& Katagan T. 2006. Anew record of Nebalia straus Risso, 1827 (Phyllocarida, Leptostraca) from the eastern Mediterranean. Crustaceana 79: 319-325. https://doi.org/10.1163/156854006776759644

Koçak C. \& Moreira J. 2015. A new Nebalia species (Crustacea, Phyllocarida, Leptostraca) from the eastern Mediterranean Sea. Journal of the Marine Biological Association of the United Kingdom 95: 1667-1675. https://doi.org/10.1017/S0025315415000946

Koçak C., Moreira J. \& Katagan T. 2007. First occurrence of Nebalia straus Risso, 1827 (Phyllocarida, Leptostraca) in the Levantine Basin (eastern Mediterranean). Crustaceana 80: 447-453. https://doi.org/10.1163/156854007780440911

Koçak C., Moreira J. \& Katagan T. 2010. New records of leptostracans (Crustacea, Phyllocarida) from the eastern Mediterranean. Turkish Journal of Zoology 34: 69-77. https://doi.org/10.3906/zoo-0901-4

Koçak C., Moreira J. \& Katagan T. 2011. New records of the genus Nebalia Leach, 1814 (Phyllocarida, Leptostraca) from the Mediterranean coast of Turkey, with a checklist of the Mediterranean species of Leptostraca. Crustaceana 84: 401-409. https://doi.org/10.1163/001121611X554346 
Latry L. \& Droual G. 2020. Leptostraca (Crustacea: Phyllocarida: Nebaliidae) from French coastal waters: new records and new data on their ecology and distribution. Cahiers de Biologie Marine 61 (1): 91-103. https://doi.org/10.21411/CBM.A.A741CE15

Ledoyer M. 1997. Leptostracés (Crustacea) de la Méditerranée. Marine Life 7 (1-2): 29-38.

Ledoyer M. 1998. Leptostracés (Crustacea) des côtes de Mauritanie récoltés au cours de la champagne Eumeli 4 en 1992 et Sarsinebalia biscayensis n. sp. de la terrasse de Meriadzek, golfe de Gascogne (Nord-Est Atlantique). Marine Life 8 (1-2): 29-33.

Ledoyer M. 2000. Leptostracés (Crustacea) de Nouvelle-Calédonie (mer de Corail, Ouest Pacifique). Marine Life 10 (1-2): 57-68.

Lee C.N.W. \& Bamber R.N. 2011. A new species of Nebalia (Crustacea: Phyllocarida: Leptostraca) from the Cape d'Aguilar Marine Reserve, Hong Kong. Zootaxa 3091: 51-59. https://doi.org/10.11646/zootaxa.3091.1.4

Lee C.N.W. \& Morton B. 2004. Temporal patterns of change in the necrophagous hyperbenthic zooplankton community of Lobster Bay, Cape d'Aguilar Marine Reserve, Hong Kong. Journal of the Marine Biological Association of the United Kingdom 84: 531-538.

https://doi.org/10.1017/S0025315404009531h

Lee C.N.W. \& Morton B. 2005. Demography of Nebalia sp. (Crustacea: Leptostraca) determined by carrion bait trapping in Lobster Bay, Cape d'Aguilar Reserve, Hong Kong. Marine Biology 148: 149157. https://doi.org/10.1007/s00227-005-0051-0

Levin L.A. 2005. Ecology of cold seep sediments: Interactions of fauna with flow, chemistry and microbes. Oceanography and Marine Biology: An Annual Review 43: 1-46.

Lo Bianco S. 1903. Le pesche abissali eseguite da F.A. Krupp col Yacht Puritan nelle adiacenze di Capri ed in altre localita del Mediterraneo. Mittheilungen aus der Zoologischen Station zu Neapel 16: 109-279.

Martin J.W., Vetter E.W. \& Cash-Clark C.E. 1996. Description, external morphology, and natural history observations of Nebalia hessleri, new species (Phyllocarida: Leptostraca), from Southern California, with a key to the extant families and genera of the Leptostraca. Journal of Crustacean Biology 16: 347-372. https://doi.org/10.1163/193724096X00153

Mauchline J. \& Gage J.D. 1983. The Nebaliacea (Crustacea: Leptostraca) of the Rockall Trough. Journal of the Marine Biological Association of the United Kingdom 63 (3): 627-631. https://doi.org/10.1017/S0025315400070934

McCormack E., Ashelby C.W. \& McGrath D. 2016. A review of the Leptostraca of the British Isles with discussion of the genus Sarsinebalia Dahl. Nauplius 24: e2016006. https://doi.org/10.1590/2358-2936e2016006

Modlin R.F. 1991. Paranebalia belizensis, a new species from shallow waters off Belize, central America (Crustacea: Malacostraca: Leptostraca). Proceedings of the Biological Society of Washington 104: 603-612.

Moreira J. \& Junoy J. 2017. First record of the genus Paranebalia Claus, 1880 (Crustacea: Leptostraca) from the Mediterranean Sea. Mediterranean Marine Science 18: 332-339.

https://doi.org/10.12681/mms.2065

Moreira J., Cacabelos E. \& Domínguez M. 2003a. Nebalia troncosoi sp. nov., a new species of leptostracan (Crustacea: Phyllocarida: Leptostraca) from Galicia, Iberian Peninsula (north-east Atlantic). Journal of the Marine Biological Association of the United Kingdom 83: 341-350. https://doi.org/10.1017/S0025315403007173h 
Moreira J., Gestoso L. \& Troncoso J.S. 2003b. Two new species of Sarsinebalia (Crustacea, Leptostraca) from the Northeast Atlantic, with comments on the genus. Sarsia 88: 189-209. https://doi.org/10.1080/00364820310001390

Moreira J., Quintas P. \& Troncoso J.S. 2004. Sobre la presencia de Nebalia strausi Risso, 1826 (Crustacea, Leptostraca) en la península Ibérica. Boletín de la Real Sociedad Española de Historia Natural (Biolología) 99: 83-92.

Moreira J., Koçak C. \& Katagan T. 2007. Nebalia kocatasi sp. nov., a new species of leptostracan (Crustacea, Phyllocarida) from Izmir Bay (Aegean Sea, eastern Mediterranean). Journal of the Marine Biological Association of the United Kingdom 87: 1247-1254.

https://doi.org/10.1017/S0025315407057487

Moreira J., Díaz-Agras G., Candás M., Señarís M.P. \& Urgorri V. 2009a. Leptostracans (Crustacea: Phyllocarida) from the Ría de Ferrol (Galicia, NW Iberian Peninsula), with description of a new species of Nebalia Leach, 1814. Scientia Marina 73 (2): 269-285. https://doi.org/10.3989/scimar.2009.73n2269

Moreira J., Moro L. \& Riera R. 2009b. Presencia de Nebalia strausi Risso, 1826 (Crustacea: Leptostraca) en las Islas Canarias. Revista de la Academia Canaria de Ciencias 21 (3-4): 99-107.

Moreira J., Sezgin M., Katagan T., Gönülal O. \& Topaloglu B. 2012. First record of a bathyal leptostracan, Nebalia abyssicola Fage, 1929 (Crustacea: Malacostraca: Phyllocarida), in the Aegean Sea, eastern Mediterranean. Turkish Journal of Zoology 36: 351-360. https://doi.org/10.3906/zoo-1012-53

Morton B. \& Lee C.N.W. 2012. The composition and spatial distribution of scavenging hyperbenthos in the Cape d'Aguilar Marine Reserve, Hong Kong. Journal of the Marine Biological Association of the United Kingdom 92 (1): 39-47. https://doi.org/10.1017/S0025315411000543

Olesen J. 1999. A new species of Nebalia (Crustacea, Leptostraca) from Unguja Island (Zanzibar), Tanzania, East Africa, with a phylogenetic analysis of leptostracan genera. Journal of Natural History 33: 1789-1809. https://doi.org/10.1080/002229399299734

Ortiz M., Winfield I. \& Cházaro-Olvera S. 2011. A new sponge-inhabiting leptostracan species of the genus Nebalia (Crustacea: Phyllocarida: Leptostraca) from the Veracruz Coral Reef System, Gulf of Mexico. Zootaxa 3027: 52-62. https://doi.org/10.11646/zootaxa.3027.1.6

Othman B.H.R., Koda T. \& Kikuchi T. 2016. A new species of Nebalia (Crustacea, Leptostraca) from coral reefs at Pulau Payar, Malaysia. ZooKeys 605: 37-52. https://doi.org/10.3897/zookeys.605.8562

Petryashov V.V. 2016. Two new species of deep-sea leptostracans (Crustacea: Phyllocarida: Leptostraca) from the North-West Pacific. Russian Journal of Marine Biology 42 (5): 383-391. https://doi.org/10.1134/S1063074016050084

Risso A. 1826. Histoire naturelle des principales productions de l'Europe méridionale et particulièrement de celles des environs de Nice et des Alpes MaritimeS. Vol. 5 Animaux Articulés, Annelides, Crustacés, Arachnides, Myriapodes et Insectes. F.-G. Levrault, Paris. https://doi.org/10.5962/bhl.title.58984

Ritt B., Desbruyères D., Caprais J.-C., Gauthier O., Ruffine L., Buscail R., Olu-Le Roy K. \& Sarrazin J. 2012. Seep communities from two mud volcanoes in the deep eastern Mediterranean Sea: faunal composition, spatial patterns and environmental control. Marine Ecology Progress Series 466: 93-119. https://doi.org/10.3354/meps09896

Roccatagliata D., Chiesa I.L., Raffo M.P. \& Gómez Simes E. 2010. On the occurrence of the genus Paranebalia (Crustacea: Phyllocarida: Leptostraca) in northern Patagonia, Argentina. Zootaxa 2349 (1): 65-68. https://doi.org/10.11646/zootaxa.2349.1.5 
Rodrigues C.F., Hilário A. \& Cunha M.R. 2013. Chemosymbiotic species from the Gulf of Cadiz (NE Atlantic): distribution, life styles and nutritional patterns. Biogeosciences 10: 2569-2581. https://doi.org/10.5194/bg-10-2569-2013

Sampaio L., Mamede R., Ricardo F., Magalhães L., Rocha H., Martins R., Dauvin J.-C., Rodrigues A.M. \& Quintino V. 2016. Soft-sediment crustacean diversity and distribution along the Portuguese continental shelf. Journal of Marine Systems 163: 43-60. https://doi.org/10.1016/j.jmarsys.2016.06.011

Sars G.O. 1870. Nye Dybvandscrustaceer fra Lofoten. Forhandlinger i Videnskabs-Selskabet i Christiana (1869): 147-174.

Sars G.O. 1896. Descriptions of the Norwegian Species at Present Known Belonging to the Sub-Orders Phyllocarida and Phyllopoda. Fauna Norvegiae Vol. 1. Descriptions of the Norwegian Species at Present Known Belonging to the Sub-orders Phyllocarida and Phyllopoda. Trykt i Aktie-bogtrykkeriet, Christiania [Oslo]. https://doi.org/10.5962/bhl.title.30839

Song J.-H. \& Min G.-S. 2017. A new species of Nebalia (Malacostraca: Phyllocarida: Leptostraca) from South Korea, with a key to the species of Nebalia Leach, 1814. Journal of the Marine Biological Association of the United Kingdom 97 (1): 59-68. https://doi.org/10.1017/S0025315415002180

Song J.-H., Kim M.-S. \& Min G.-S. 2012a. First record of Paranebalia longipes (Crustacea: Phyllocarida: Leptostraca) from South Korea. Animal Systematics, Evolution and Diversity 28: 221229. https://doi.org/10.5635/ASED.2012.28.4.221

Song J.-H., Moreira J. \& Min G.-S. 2012b. A new species of Leptostraca, Nebalia koreana (Malacostraca: Phyllocarida), from South Korea. Journal of Crustacean Biology 32: 641-653. https://doi.org/10.1163/193724012X638482

Song J.-H., Moreira J. \& Min G.-S. 2013. Description of a new species of Leptostraca, Nebalia pseudotroncosoi n. sp. (Crustacea: Malacostraca), from South Korea, with peculiar sexual dimorphism. Journal of Crustacean Biology 33: 124-136. https://doi.org/10.1163/1937240X-00002106

Song J.-H., Park T. \& Min G.-S. 2017. First report of Leptostraca from South-east Asia: Nebalia cambodiana sp. nov. (Crustacea: Malacostraca). Journal of the Marine Biological Association of the United Kingdom 97 (6): 1343-1349. https://doi.org/10.1017/S0025315416000618

Tomassetti P., Gennaro P., Lattanzi L., Mercatali I., Persia E., Vani D. \& Porrello S. 2016. Benthic community response to sediment organic enrichment by Mediterranean fish farms: Case studies. Aquaculture 450: 262-272. https://doi.org/10.1016/j.aquaculture.2015.07.019

Vader W. 1973. Nebalia typhlops in western Norway (Crustacea Leptostraca). Sarsia 53: 25-28. https://doi.org/10.1080/00364827.1973.10411244

Vetter E.W. 1996a. Enrichment experiments and infaunal population cycles on a Southern California sand plain: response of the leptostracan Nebalia daytoni and other infauna. Marine Ecology Progress Series 137: 83-93. https://doi.org/10.3354/meps137083

Vetter E.W. 1996b. Nebalia daytoni n. sp., a leptostracan from Southern California (Phyllocarida). Crustaceana 69: 379-386. https://doi.org/10.1163/156854096X00970

Walker-Smith G.K. 1998. A review of Nebaliella (Crustacea: Leptostraca) with the description of a new species from the continental slope of southeastern Australia. Memoirs of the Museum of Victoria 57 (1): 39-56. https://doi.org/10.24199/j.mmv.1998.57.02

Walker-Smith G.K. 2000. Levinebalia maria, a new genus and new species of Leptostraca (Crustacea) from Australia. Memoirs of the Museum of Victoria 58 (1): 137-148.

https://doi.org/10.24199/j.mmv.2000.58.7 
Walker-Smith G.K. \& Poore G.C. 2001. A phylogeny of the Leptostraca (Crustacea) with keys to families and genera. Memoirs of Museum Victoria 58 (2): 383-410. https://doi.org/10.24199/j.mmv.2001.58.21

Watling L. 1989. A classification system for crustacean setae based on the homology concept. In: Felgenhauer B.E., Watling L. \& Thistle A.B. (eds) Functional Morphology of Feeding and Grooming in Crustacea. Crustacean Issues 6: 15-26.

Manuscript received: 3 September 2020

Manuscript accepted: 11 December 2020

Published on: 2 March 2021

Topic editor: Rudy Jocqué

Desk editor: Kristiaan Hoedemakers

Printed versions of all papers are also deposited in the libraries of the institutes that are members of the EJT consortium: Muséum national d'histoire naturelle, Paris, France; Meise Botanic Garden, Belgium; Royal Museum for Central Africa, Tervuren, Belgium; Royal Belgian Institute of Natural Sciences, Brussels, Belgium; Natural History Museum of Denmark, Copenhagen, Denmark; Naturalis Biodiversity Center, Leiden, the Netherlands; Museo Nacional de Ciencias Naturales-CSIC, Madrid, Spain; Real Jardín Botánico de Madrid CSIC, Spain; Zoological Research Museum Alexander Koenig, Bonn, Germany; National Museum, Prague, Czech Republic. 